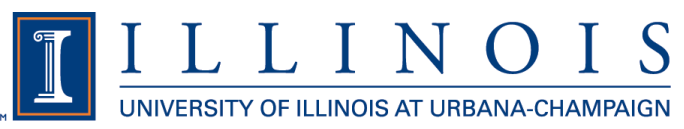

Prairie Research Institute

\title{
Status of Endangered and Threatened Sand Area Species of the Illinois Flora
}

Loy R. Phillippe, Brenda Molano-Flores,

Michael J.C. Murphy, Paul B. Marcum, and John E. Ebinger 


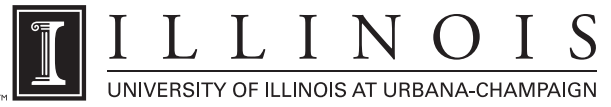

\author{
Prairie Research Institute \\ William Shilts, Executive Director \\ Illinois Natural History Survey \\ Brian D. Anderson, Director \\ Forbes Natural History Building \\ 1816 South Oak Street \\ Champaign, Illinois 61820 \\ 217-333-6880
}

\title{
Citation:
}

Phillippe, L.R., B. Molano-Flores, M.J.C. Murphy, P.B. Marcum, and J.E. Ebinger. 2011. Status of endangered and threatened sand area species of the Illinois flora. Illinois Natural History Survey Bulletin 39(4):259-296.

For permissions, contact the Prairie Research Institute.

Editor: Charles Warwick

US ISSN 0073-4918

US ISBN 1-882932-27-7

$\mathrm{P} 0486640-.45 \mathrm{M}-07 / 2011$

(C) 2011 University of Illinois Board of Trustees. All rights reserved.

Printed with soy ink on recycled and recyclable paper.

The University of Illinois will not engage in discrimination or harassment against any person because of race, color, religion, national origin, ancestry, age, marital status, disability, sexual orientation including gender identity, unfavorable discharge from the military or status as a protected veteran and will comply with all federal and state nondiscrimination, equal opportunity and affirmative action laws, orders and regulations. This nondiscrimination policy applies to admissions, employment, access to and treatment in University programs and activities.

University complaint and grievance procedures provide employees and students with the means for the resolution of complaints that allege a violation of this Statement. Inquiries or complaints may be addressed to the Director and Assistant Chancellor, Office of Equal Opportunity and Access, 601 East John Street, Swanlund Administration Building, (217) 333-0885, fax (217) 244-9136, TTY (217) 244-9850 or the Associate Provost and Director, Academic Human Resources, Henry Administration Building, (217) 333-6747, fax (217) 244-5584. For other University of Illinois information, contact University Directory Assistance at 333-1000. 


\section{Status of Endangered and Threatened Sand Area Species of the Illinois Flora}

Loy R. Phillippe, Brenda Molano-Flores,

Michael J.C. Murphy, Paul B. Marcum, and John E. Ebinger 


\section{Status of Endangered and Threatened Sand Area Species of the Illinois Flora}

Loy R. Phillippe, Brenda Molano-Flores,

Michael J.C. Murphy, Paul B. Marcum, and John E. Ebinger 


\section{CONTENTS}

Acknowledgments................................................................................. vi

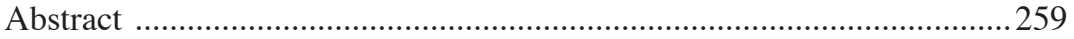

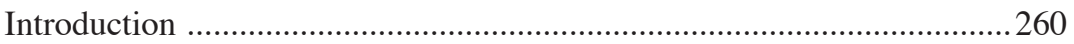

Origin and Distribution of Illinois Sand Deposits ...................................260

Grand Prairie Natural Division, Kankakee Sand Area Section..................262

Grand Prairie Natural Division, Green River Lowlands Section...............262

Illinois River and Mississippi River Sand Areas Natural Division,

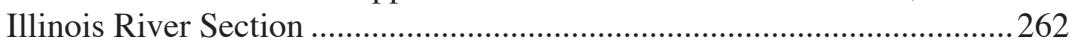

Illinois River and Mississippi River Sand Areas Natural Division,

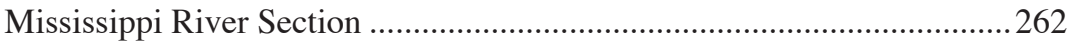

Northeastern Morainal Natural Division, Chicago Lake Plain Section.....263

Northeastern Morainal Natural Division, Lake Michigan Dunes Section. 263

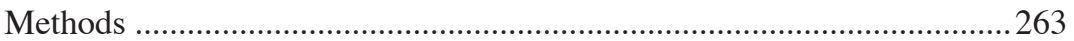

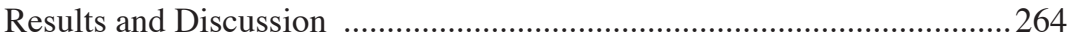

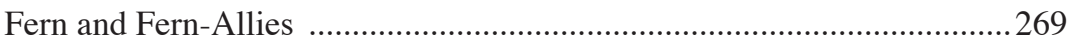

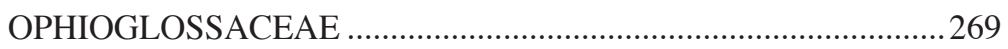

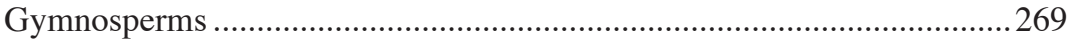

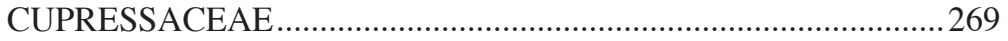

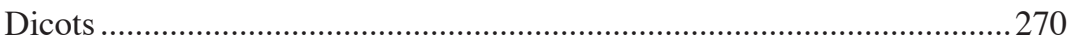

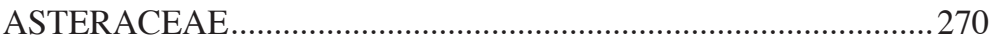

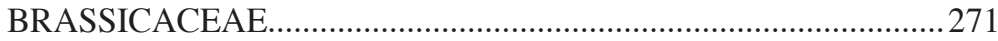

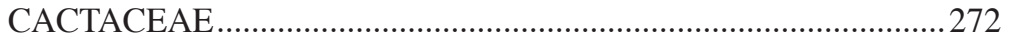

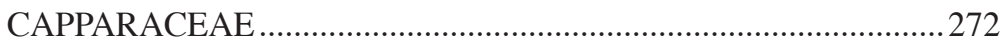

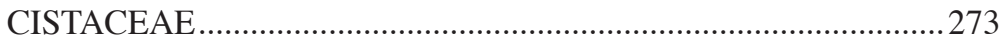

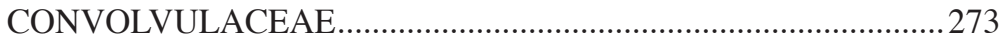

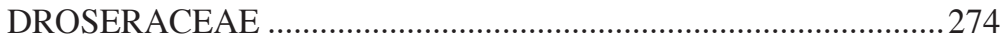




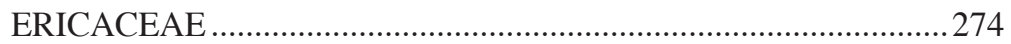

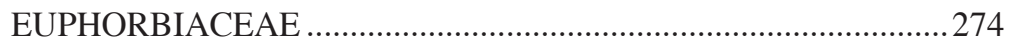

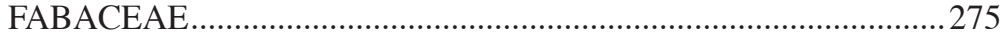

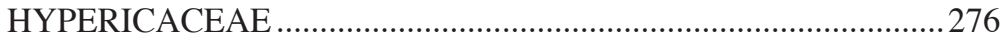

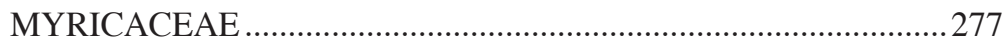

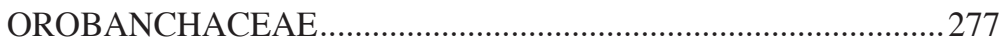

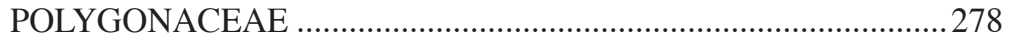

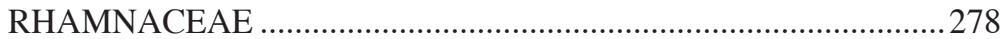

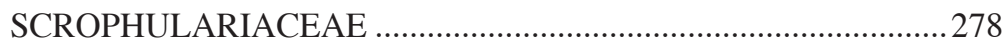

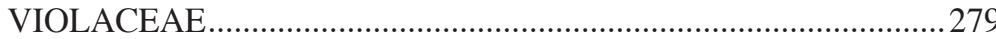

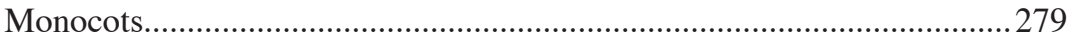

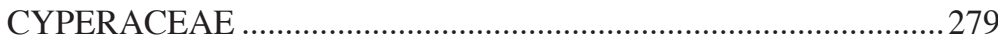

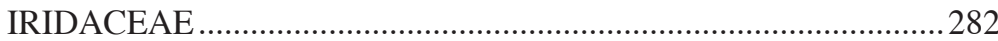

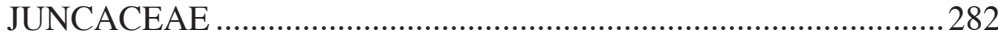

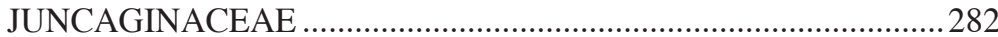

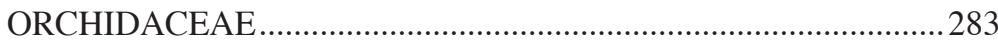

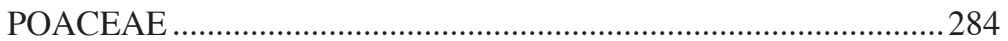

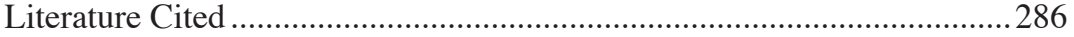




\section{ACKNOWLEDGMENTS}

The authors thank the Illinois Department of Natural Resources, the Illinois Nature Preserves Commission, the Illinois Endangered Species Protection Board, and the Illinois Department of Transportation for the use of their databases and for financial support to complete this project. Many amateur and professional plant taxonomists and other interested individuals are also thanked for their interest and help. The members of the Endangered Species Advisory Committee of the Endangered Species Protection Board were very helpful in obtaining the information needed to complete this manuscript. We also thank the curators of the many herbaria for allowing us to use their facilities and for their help in locating and sending requested specimens. Special thanks go to Ms. Tara Kieninger, Illinois Department of Natural Resources, Dr. Gordon Tucker, Eastern Illinois University, Dr. Suzanne Masi, Chicago Botanic Garden, Ms. Janet Jarvis, Illinois Natural History Survey, and three anonymous reviewers who greatly improved the quality of the manuscript. 


\begin{abstract}
This study was undertaken to determine the distribution and habitat requirements of many of the endangered and threatened plant species associated with the sand deposits of Illinois. Approximately 70 species of endangered and threatened plants are known to grow in these deposits. The habitat fidelity and natural community types were determined for 40 of these species that are restricted to these glacial drift sand habitats. Plant community types, associated species, moisture requirements, and other data concerning each of the plant species were determined by reviewing the pertinent literature, searching the Illinois Department of Natural Resources Natural Heritage Database, through discussions with botanists and natural heritage biologists, examination of herbarium specimens, and our studies of the vegetation of the Illinois sand deposits. Throughout the course of these studies, most of the nature preserves, state parks, and identified natural areas in the sand regions were visited on numerous occasions and vegetation surveys undertaken. The information presented in this paper could allow rare plant conservation in Illinois to become more proactive by encouraging the selection of sites where in situ conservation efforts could be conducted by state, local, and nongovernmental organizations.
\end{abstract}




\section{INTRODUCTION}

Most of the endangered and threatened species of Illinois are restricted to one or a few natural divisions, and have growth requirements based on climate and habitat specificity found in these regions. These natural divisions are distinguished on the basis of topography, glacial history, bedrock, soil, climate, and the distribution of native plants and animals (Schwegman 1973). Generally, these endangered and threatened species have typically associated species, and mostly occur in only one, or a few, natural communities within a natural division. These natural communities are outlined in White and Madany (1978), and are based on vegetation structure (forest, prairie, savanna, etc.), topographic position, soil texture, structure, and moisture (xeric, mesic, hydric). Any management strategies used to preserve endangered and threatened plants must focus on these natural divisions and the natural communities (habitat types) in which these species normally occur.

The present study was undertaken to determine the habitat requirements of a group of endangered and threatened plant species that are mostly restricted to communities occurring in the Illinois sand deposits. Presently, more than 70 endangered and threatened plant species are known to grow in these deposits and occur in habitats ranging from sand prairies, sand forests, sand savannas, to various wetland sand communities. During the present study, we determined the habitat fidelity and natural community type(s) of 40 species that are associated with these sand deposits. Some of the material included as part of this article is based on a report prepared for the Illinois Endangered Species Protection Board (Phillippe et al. 2006).

\section{ORIGIN AND DISTRIBUTION OF ILLINOIS SAND DEPOSITS}

At the time of European settlement, aeolian (wind-blown) sand deposits covered approximately $3.4 \%$ (497,248 ha or 1,228,202 acres) of the total land area of Illinois (Lineback 1979, Fehrenbacher et al.1984). The majority of these deposits $(>85 \%)$ occur in the northern half of the state, and most are on glacial outwash plains resulting from erosion events associated with Wisconsin glaciation (Fig. 1; Willman and Frye 1970, King 1981). In the late 1970s, the Illinois Natural Areas Inventory found that less than $0.5 \%$ of these sand deposits still contained high-quality sand communities (White 1978). The most extensive sand areas are the Kankakee sand deposits of northeastern Illinois and the Illinois River sand deposits in the central part of the state (Fig. 1). Smaller deposits include the Green River Lowlands in northwestern Illinois (Gleason 1910, Schwegman 1973), deposits associated with the floodplain of the Mississippi River in northwestern Illinois, and the Chicago Lake Plain and beaches along Lake Michigan in northeastern Illinois (Fig. 1; Willman and Frye 1970, Schwegman 1973).

Most of these sand deposits, commonly referred to as Parkland Sand or the Parkland Formation, consist of windblown sand in dunes and in sheetlike deposits between and bordering the dunes (Willman and Frye 1970). The dunes are usually found on terraces along major river valleys in the northern half of Illinois, and consist of medium-grained sands that are sorted by wind from the underlying glacial outwash. These sands were reworked by wind, forming the dune and swale topography characteristic of these deposits. Dunes to $12 \mathrm{~m}$ high are common, with some as high as $30 \mathrm{~m}$. In the Mississippi River valley in northwestern Illinois, the dunes have migrated onto the bluffs and uplands to the east of the terraces. Dunes were also common features on the beaches of glacial Lake Chicago.

Some of the most comprehensive early research completed on the vegetation of Illinois sand deposits was undertaken in the early 1900s by Henry Allan Gleason (Hart and Gleason 1907, Gleason 1910), an ecologist and plant geographer at the Illinois Natural History Survey, and by Arthur G. Vestal, a botanist at the University of Illinois (Vestal 1913). These authors described the dominant plant communities of the Illinois sand deposits and discussed the animals, particularly insects, associated with these habitats. In these early studies, 


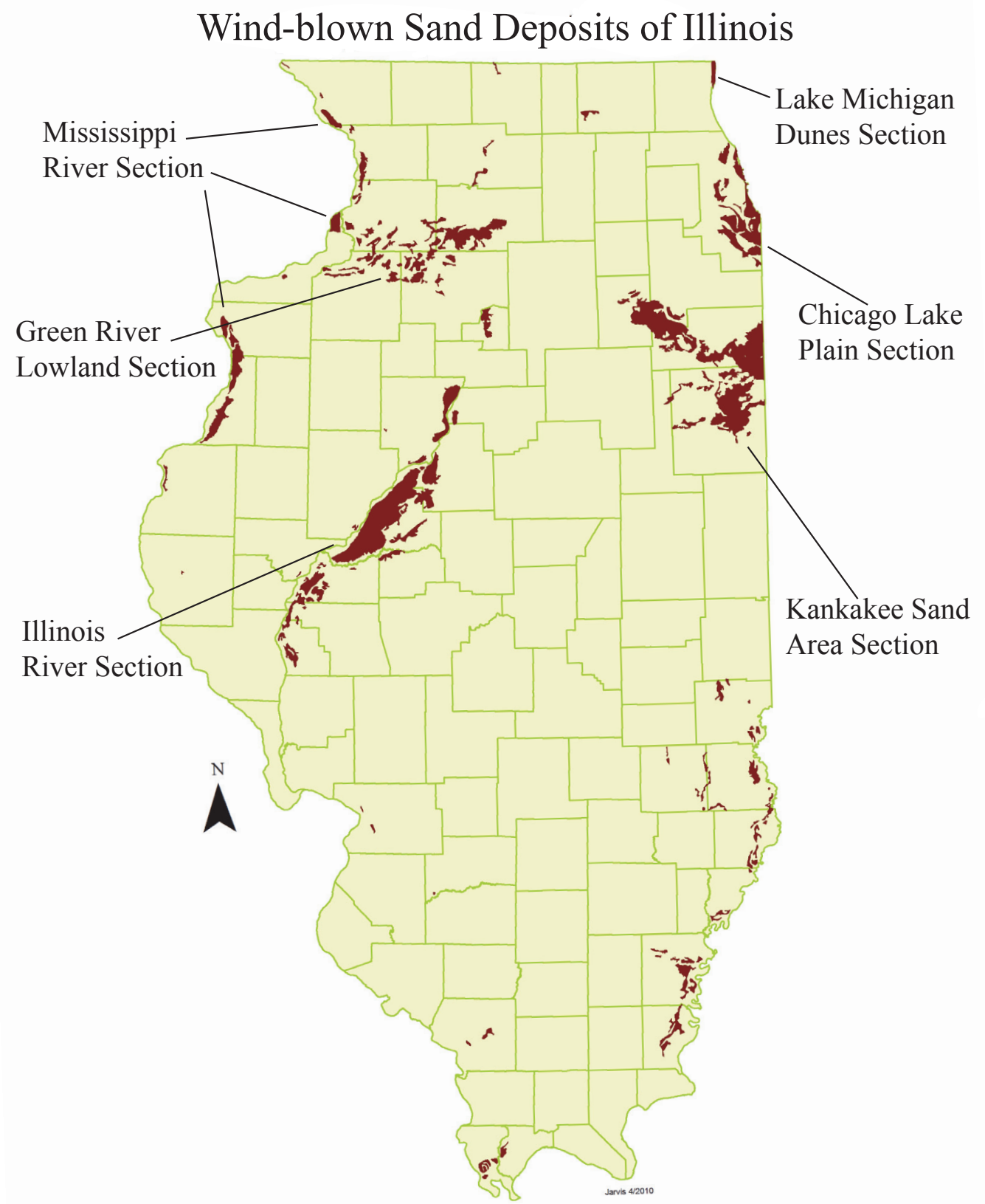

Figure 1. Map showing locations of Illinois' major wind-blown sand deposits. 
community composition and structure were discussed in detail. Additionally, these studies were completed at a time when large areas of these sand communities had not been extensively modified by cultivation, grazing, and/or fire-suppression. The major glacial drift sand deposits of Illinois are discussed below.

\section{Grand Prairie Natural Division, Kanka- kee Sand Area Section: The extensive sand} deposits occurring in the Kankakee area (Fig. 1) were deposited approximately 14,000 to 16,000 years ago by glacial melt waters flowing from the retreating Laurentide ice sheet (Wisconsin glaciation), which in some instances resulted in catastrophic floodwater events (e.g., Kankakee Torrent; Frankie et al. 1996, Wiggers 1997, Killey 1998b). Large amounts of sandy materials were deposited by these melt-waters in various areas within this region, including previously formed glacial lakes (Lake Wauponsee, Lake Watseka), outwash plains, and stream channels (Willman and Frye 1970, Lineback 1979, Frankie et al. 1996). After the waters receded from episodes of glacial floodwater activity, many of the sand deposits were later sorted and reworked into dunes and sheetlike formations by strong winds (Willman and Frye 1970, Frankie et al. 1996). Additionally, floods sometimes removed many of these deposits from the landscape and redeposited them elsewhere in the state, in turn depositing new materials upon which the physical processes of weathering, sorting, and transporting would begin again (Willman and Frye 1970, Schwegman 1973).

\section{Grand Prairie Natural Division, Green River}

Lowlands Section: The relatively extensive Green River sand deposits cover the southern half of Whiteside County, most of the northern half of Henry County, and small parts of Bureau and Lee counties in northwestern Illinois (Fig. 1). Located just to the west of the terminal moraine of Wisconsin glaciation, extensive amounts of sand and gravel were deposited over the existing Illinoian till during intermittent warm periods of the Wisconsin Episode (Killey 1998a). These sands were reworked by wind, creating numerous small sand dunes (Willman and Frye 1970). Except for local "blowouts," these dunes were formed soon after the sand was exposed to wind action, and most have long been stabilized in their present position by vegetation.

\section{Illinois River and Mississippi River Sand Areas Natural Division, Illinois River Sec-} tion: Melt waters associated with the Kankakee area were discharged into the Kankakee River Valley, mostly during major flooding events (e.g., Kankakee Torrent; Willman and Frye 1970, Willman 1973). The Kankakee Valley could not accommodate these extensive floods and at peak flow the water spread over the surrounding uplands. During these flooding events, large quantities of sand were removed from the Kankakee area and transported by the Kankakee River into the Illinois River. Much of the Illinois River sand deposits (Fig. 1) were formed during the Kankakee Torrent. The outlet channel for the Kankakee Torrent was along the Illinois River Valley and the torrent, which was entrenched in bedrock, moved rapidly and scoured broad areas of bedrock. Below the "Big Bend" at present day Hennepin, Illinois, however, the Kankakee Torrent entered a wider and more easily eroded section of the Illinois River Valley. In this wider valley, the Kankakee Torrent slowed and much of the gravel and sand being carried was deposited, particularly below present day Peoria. The broad terraces present along the Illinois River Valley from Hennepin to Beardstown are mostly erosion surfaces of the Kankakee Torrent and many are presently covered with sand and gravel deposits. These deposits, located in the southern half of Tazewell County, nearly all of Mason County, and small parts of Cass, Marshall, Morgan, Peoria, Putnam, Scott, and Woodford counties, comprise the Illinois River Section of the Illinois River and Mississippi River Sand Areas Natural Division (Fig. 1; Schwegman 1973)

\section{Illinois River and Mississippi River Sand Areas Natural Division, Mississippi River} Section: Many small sand deposits are scattered throughout the lowlands of the Missis- 
sippi River and its tributaries, extending from Jo Daviess County south to Hancock County (Fig. 1; Schwegman 1973). Some of these deposits were formed when the glacial Lakes Milan and Cordova, located in present day Carroll, Henry, Rock Island, and Whiteside counties, drained, leaving behind sandy lakebed sediments. Others were deposited during catastrophic flood events associated with the retreat of the Wisconsin Glacier. These flood events occurred when moraines and/or ice dams north of Illinois, which were impounding vast amounts of glacial melt-waters, were breached. The resulting torrents of water carried large quantities of sand and other glacial outwash materials southward.

\section{Northeastern Morainal Natural Division, Chicago Lake Plain Section: This area (Fig.}

1) is the most recently glaciated part of Illinois. The soils were derived from lakebed sediments deposited by glacial Lake Chicago, which at one time had an elevation about $4.6 \mathrm{~m}$ higher than present Lake Michigan (Willman and Frye 1970). This flat, poorly drained section contained long, low ridges that represent ancient shoreline deposits of glacial Lake Chicago. The original vegetation was mostly prairie and marsh with black oak-scrub forests on the ancient shoreline ridges. The original vegetation of nearly the entire section has been lost with small remnants still present at isolated nature preserves.

\section{Northeastern Morainal Natural Division, Lake Michigan Dunes Section: The Lake} Michigan Dunes Section (Fig. 1) is generally recognized as a small separate unit based on the presence of multiple shoreline species, many of which occur nowhere else in Illinois. The dunes and swales of this narrow section of Lake Michigan shoreline consist of some sand-binding species not associated with the inland sand deposits of Illinois. These shoreline habitats were formed by the continual shifting of sand by wind and wave action upon the stabilizing vegetation, resulting in a wide vartiety of plant associations that correspond to various stages of plant succession.

\section{METHODS}

During the past 12 years, the authors have been studying the vegetation of the Illinois sand deposits. Throughout the course of these studies, most of the nature preserves, state parks, and listed natural areas in the sand regions were visited. While identifying and documenting the vegetation of these areas, the authors observed and vouchered many of the endangered and threatened species that have been incorporated into this present study. The structure and composition of the plant communities, which contain many of these endangered species, have been determined, and much of these data have been published elsewhere.

Plant community types, associated species, moisture requirements, and other information concerning each of the plant species commonly associated with Illinois sand deposits were determined by reviewing the published literature and the Illinois Department of Natural Resources Natural Heritage Database (Kieninger 2009a) and the examination of herbarium specimens as well as many of the state's populations of these species.

The Illinois Department of Natural Resources Natural Heritage Database (Kieninger 2009a) was used to determine the current population status of many endangered and threatened plant species. Biologists from the Illinois Department of Natural Resources and botanists throughout the state routinely update information on many of the rare and listed species. Commonly, this information includes recent sightings of rare species, habitat information, extent and size of populations, as well as management activities at these sites. Since these sightings are not vouchered, we did not use the information for county records (which are based on herbarium specimens), but commonly listed this information in the species population status. Knowing many of the biologists reporting these records, we are confident that the sightings are accurate. Without a voucher specimen deposited in a public herbarium, however, we feel that the information cannot be used to verify a species location.

The herbaria listed below were searched for specimens of endangered and threatened 
sand species. When located, the label information for each specimen was recorded and specimen identification verified. The information commonly found on labels included scientific name of the specimen along with ecological data, locality, date collected, and collector (s). This information was submitted to the Illinois Endangered Species Protection Board, Illinois Department of Natural Resources, Springfield.(Phillippe et al. 2006). Listed below (alphabetically by acronym) are the locations and acronyms of the herbaria where specimens were examined: Chicago Academy of Science, Chicago, Illinois (CHAS); Chicago Botanic Garden, Glencoe, Illinois (CHIC); Northern Illinois University, DeKalb, Illinois (DEK); Eastern Illinois University, Charleston, Illinois (EIU); Field Museum of Natural History, Chicago, Illinois (F); Gray Herbarium of Harvard University, Cambridge, Massachusetts (GH); University of Illinois, Urbana, Illinois (ILL); Illinois Natural History Survey, Champaign, Illinois (ILLS); Indiana University, Bloomington, Indiana (IND); Illinois State Museum, Springfield, Illinois (ISM); Illinois State University, Normal, Illinois (ISU); Knox College, Galesburg, Illinois (KNOX); Missouri Botanical Garden, St. Louis, Missouri (MO); The Morton Arboretum, Lisle, Illinois (MOR); Western Illinois University, Macomb, Illinois (MWI); Natural Land Institute, Rockford, Illinois (NLI); Rockford College, Rockford, Illinois (RCH); and Southern Illinois University, Carbondale, Illinois (SIU).

\section{RESULTS AND DISCUSSION}

Sand Communities: Moisture levels within sand communities can be highly variable and, to a large degree, influence vegetation composition and structure. Dry habitats are often characteristic of sand deposits, and the associated species are those adapted to xeric conditions. Some of these open sands are desertlike with cactus (Opuntia spp.) being common. Many sand habitats, however, are mesic to wet, particularly where the water table is at or near the surface. Under these conditions, hydric vegetation dominates (White and Madany 1978).

Plant communities of sand deposits are diverse and include sand ponds (McClain et al. 1997, Ebinger et al. 2007, Murphy et al. 2009), seeps (McClain et al. 2008), marshes and sedge meadows (Handel et al. 2003, Feist et al. 2008), prairies (Handel et al. 2003, McClain et al. 2003, 2004a, 2004b, 2005; Phillippe et al. 2004, 2008; Ebinger et al. 2007), savannas and woodlands (McDowell et al. 1983; Johnson and Ebinger 1992 1995; McClain et al. 2002; Phillippe et al. 1999, 2002a, 2002b, 2003a, 2008), closed forests (Jenkins et al. 1991; Coates et al. 1992; Phillippe et al. 2003b, 2009; Ebinger et al. 2007), and flatwoods (McDowell et al. 1983). Listed and described below are the natural communities found in the sand deposits of Illinois and the endangered and threatened plant species commonly associated with these communities (White and Madany 1978).

Lake Shore Beach: On the beach of Lake Michigan in Cook and Lake counties, the growing conditions are harsh and the resulting vegetation is composed of species that are adapted to xeric conditions. In this community, exposed sand is the dominant feature with blowing and shifting sand being a common occurrence. Species diversity, however, is relatively high with many of the rare species being clumped and locally common (Bowles et al. 1993). Endangered and threatened species associated with the beach include: Ammophila breviligulata, Cakile edentula, Chamaesyce polygonifolia, and Lathyrus maritimus.

Lake Shore Foredunes: In the foredunes of the Lake Michigan shore, bare sand is obvious, but a fairly dense cover of vegetation is present with low shrubs and some prairie species common. In this community, the sand is more stable than on the beach and some humus is present in the soil. Endangered and threatened species associated with the foredunes include: Arctostaphylos uva-ursi, Cirsium pitcheri, Hypericum kalmianum, Juniperus communis, and Juniperus horizontalis.

Within the beach and foredunes is a mosaic of communities, each with distinct habitat requirements and associated plant and 
animal species. These communities include marshes, fens, and pannes. A few endangered and threatened plant species are associated with these habitats, but we did not study a sufficient number of species to adequately describe and define these habitat types. These species, which are associated with these sandy, wet communities include: Juncus alpinoarticulatus, Platanthera flava var. herbiola, Scirpus microcarpus, and Triglochin maritima.

Dry to Dry-mesic Sand Prairie: Dry and drymesic sand prairies are common in all Illinois sand deposits. In presettlement time, dry sand prairies dominated the ridges and upper slopes of sand dunes and commonly continued into the sand savannas and to the edges of sand forests that were dominated by Quercus velutina.

In mature dry sand prairies, the dominant grasses were usually Schizachyrium scoparium and Dichanthelium villosissimum, with important forbs being Ambrosia psilostachya, Lespedeza capitata, Solidago nemoralis, and Opuntia spp. (McClain et al. 2003, 2004a; Phillippe et al. 2004; Ebinger et al. 2006, 2008, 2009). In mature dry-mesic sand prairies, most of these species are still common, but there is an increase in the dominant grasses including Sorghastrum nutans and sometimes Andropogon gerardii (Ebinger et al. 2006). Endangered and threatened species associated with mature dry to dry-mesic sand prairies include: Bouteloua gracilis, Carex inops subsp. heliophila, Ceanothus herbaceus, Comptonia peregrina, Opuntia fragilis, Orobanche fasciculata, Penstemon grandiflorus, and Stylisma pickeringii.

Presently, degraded dry and dry-mesic sand prairies are found in many Illinois nature preserves and natural areas. These communities vary from sand prairies with relatively minor disturbances to those that have been nearly destroyed. Usually, non-native species may dominate sections of the disturbed sand prairie. Non-native cool-season grasses, such as Poa pratensis, are common, and woody invasion is usually pronounced with exotic species common. The turnover of sand caused by burrowing animals and other natural and anthropogenic disturbances may be important in maintaining the habitat for some endangered and threatened plant species including: Astragalus distortus, Baptisia tinctoria, Botrychium matricariifolium, Hymenopappus scabiosaeus, and Lesquerella ludoviciana.

Areas of blowing sand are generally associated with dune ridges where dry sand prairies were originally found. These treeless areas, with low vegetation cover, are the result of past disturbances, particularly off-road vehicle use, but also excessive grazing and other anthropogenic activities. Any disturbance that opens the dry ridge to wind creates the potential for the development of a blowing sand community. All blowouts examined had sparse vegetation cover and low species diversity. Covering up to three or more hectares, blowouts are found in all the major sand deposits of Illinois. They are most abundant, and largest, in the Mississippi River sand deposits (Ebinger et al. 2006). Endangered and threatened species associated with the blowouts in dry sand prairies include: Cyperus grayoides, Hudsonia tomentosa, Lesquerella ludoviciana, Polanisia jamesii, and Stylisma pickeringii

Wet to Wet-mesic Sand Prairies: Wet to wetmesic sand prairies are relatively common in Illinois sand deposits. In presettlement times, these sand prairies dominated the lower slopes of dunes and most of the lowlands between dunes. Generally, the lower slopes of the dunes contained mesic to wet-mesic sand prairies. Near the base of the slopes, wet sand prairies were common, while lower flat areas were dominated by wet prairies or marshes, depending on the extent and duration of inundation. In this swell and swale topography, sand ponds existed in depressions of these marshes, while the excessive accumulation of peat produced by Carex stricta in shallow depressions resulted in the formation of sedge meadows.

In mature wet-mesic sand prairies, surface water is common for short periods and the soils are high in organic material and slightly acidic. The dominant grasses are usually Andropogon gerardii, Calamagrostis canadensis, Sorghastrum nutans, and Spartina pectinata, while various species of Carex are also common. Important forbs include Euphorbia corollata, 
Euthamia gymnospermoides, Liatris aspera, Parthenium integrifolium, Pycnanthemum virginicum, and Solidago canadensis (Ebinger et al. 2008, 2009).

In wet sand prairies, water is present for longer periods and the soils contain excessive peat. In this community, many of the species associated with wet-mesic sand prairies are common. Generally, there is a decrease in the number of species and abundance of most grasses, but Calamagrostis canadensis and Spartina pectinata usually become more important. Carex species (mostly Carex stricta), as well as other members of the Cyperaceae, are important species in these prairies. Important forbs include Galium obtusum, Helianthus grosseserratus, Hypericum sphaerocarpum, Silpium integrifolium, Solidago canadensis, and Thelypteris palustris, (Handel et al. 2003; Feist et al. 2008; Ebinger et al. 2008, 2009). Endangered and threatened species associated with mature wet to wet-mesic sand prairies included Carex cumulata, Drosera intermedia, Hypericum adpressum, Platanthera ciliaris, Platanthera flava var. herbiola, Polygonum careyi, Sisyrinchium atlanticum, and Viola primulifolia.

Degraded wet and wet-mesic sand prairies are common and usually have associated endangered and threatened species. On these degraded prairie remnants, non-native species are common and may dominate while woody invasion may be extensive (Feist et al. 2008, Ebinger et al. 2008, 2009). Exposed sand due to burrowing animals as well as anthropomorphic causes may be important in maintaining habitat for some species. Many of the endangered and threatened species that occur in these habitats are found near the edges of the prairie and in areas of heavy human disturbances; particularly spoil from drainage ditches, in drainage ditches, and on abandoned roadsides. It appears that human disturbances may be important in maintaining the habitat for some endangered and threatened plant species including Carex cumulata, Hypericum adpressum, Polygonum careyi, Sisyrinchium atlanticum, and Viola primulifolia.
Sand Flatwoods: Sand flatwoods are rarely encountered in Illinois, being restricted to the Kankakee River sand deposits and the Chicago Lake Plain. These flatwoods occur in depressions between dunes where the water table is at or near the surface of the ground for extended periods of time in winter and spring. Sometimes water is present throughout the year. The peaty soils are acidic and consist of fine sandy loams with high concentrations of organic material. Quercus palustris is consistently the dominant species with a few individuals of Quercus alba and Nyssa sylvatica on slightly raised areas (McDowell et al. 1983, McFall and Karnes 1995). Endangered and threatened species associated with sand flatwoods include Carex cumulata, Comptonia peregrina, Drosera intermedia, Polygonum careyi, and Viola primulifolia.

Sand Ponds: Sand ponds are mostly transient communities that are relatively common in the Illinois River sand deposits of central Illinois in Cass and Mason counties (McClain et al. 1997), and the Green River Lowlands (Ebinger et al. 2008, 2009). Many of these ponds are temporary, being dry in some years. The species associated with the ponds persist within the soil seed bank, and in drought years many of these ponds are farmed. During these years, the species associated with these ponds do not grow, but do reappear during times of high precipitation (Schwegman 1984). These shallow ponds, most of which become dry at least in some years, have long been known for rare vascular plant species. These shallow depressions, some less than a meter deep and extending for many hectares, were once common in the lowlands between the widely spaced dunes, particularly in the Illinois River sand deposits.

The early successional stages in these temporary wetlands, particularly areas that are farmed in most years, generally consist of many annual and a few perennial plant species. Some of the species have propagules that remain in the seed bank for extended periods, while others are transported into the area by wind and water birds (Robinson 1995). The resulting plant community depends on the life histories 
of the species involved plus their propagule longevity and establishment requirements (van der Valk 1981, Visocky 1995). In temporary sand ponds, the time between flooding events may be fairly extensive (20 years or more), and propagule longevity may be a critical factor in determining plant community composition. Before extensive modification of the landscape by humans, the flooding regime may have been more regular and with fewer years separating each cycle. Endangered and threatened species associated with sand ponds include Fimbristylis vahlii and Schoenoplectus hallii.

Gravel Prairies: Gravel prairies are associated with valley train deposits along a few rivers and streams in central and northern Illinois. Occurring on kames and eskers, mostly in the Northeastern Morainal Division and on the slopes of gravel terraces along major rivers, few of these gravel prairies have been studied. Presently, dry gravel prairies are rare in Illinois, most having been destroyed by mining operations. Very little information is available concerning the flora of gravel prairies in Illinois. Along the Rock River in Winnebago County, Fell and Fell (1956) listed the typical grasses on the gravel prairie crest as Bouteloua curtipendula, Schizachyrium scoparium, and Sporobolus heterolepis. More recently, Post et al. (1985) studied three gravel prairies along Wea Creek, a tributary of the Wabash River in north-central Indiana. These prairies, all located in Harrison County, Indiana, had the visual aspect of a midgrass prairie. Here the common grasses were Bouteloua curtipendula, Heterostipa spartea, and Schizachyrium scoparium.

On a gravel prairie of the Illinois River valley, McClain et al. (2004b) recorded Schizachyrium scoparium as the dominant species, being four times more abundant than any other plant species. Other grasses included Bouteloua curtipendula, Dichanthelium oligosanthes, Sorghastrum nutans, and Sporobolus clandestinus, while common forbs included Ambrosia psilostachya, Dalea purpurea, Echinacea pallida, and Opuntia humifusa. Endangered and threatened species associated with gravel prairies include Ceanothus herbaceus, Penstemon grandiflorus, and Tetraneuris herbacea.
Species Accounts: Of the 40 species examined, all were listed as endangered or threatened in Illinois (Table 1). Each of these taxa either occurs exclusively within these sand communities, or has great affinity to these communities, rarely occurring in habitats not associated with windblown, glacial sand deposits. Endangered and threatened species that are only occasionally associated with the major sand deposits of Illinois were not included in this study. Some species of this group of approximately 30 species occasionally are found in glacial sand deposits, but most collections are associated with river sands. We recorded and vouchered these species when they were encountered, but they were of minimal occurrence in the wind-blown glacial sand deposits and are not included in this study.

For the species discussed below, their scientific and common names are listed first (Illinois Endangered Species Protection Board 2005, 2009), followed by names used in Mohlenbrock (2002). These are followed by the Illinois counties for which we have been able to locate herbarium vouchers (sight records or observational records listed in this article were not considered vouchered reports). The herbaria where these vouchers are located are recorded by their acronyms listed in the "Methods" section of this paper. Then, the status of each species is listed (endangered or threatened) along with the date the species was listed. This information is followed by a general description of the species' geographic range, its distribution in Illinois along with its habitat requirements, and usually where the species is still known to occur in the state, with particular reference to the state nature preserves where it does, or has, occurred. Listed next are Illinois collections where we give the first Illinois collection (s) of this species that we could locate. This is commonly followed by one, or a few, early collections from other counties. The Illinois literature is then listed, usually including some early references of the species' distribution and habitat requirements, and more recent information on taxonomic and ecological studies about the species.

Scott and Molano-Flores (2007) observed that rare plant conservation efforts are more reactive than proactive. The information presented 


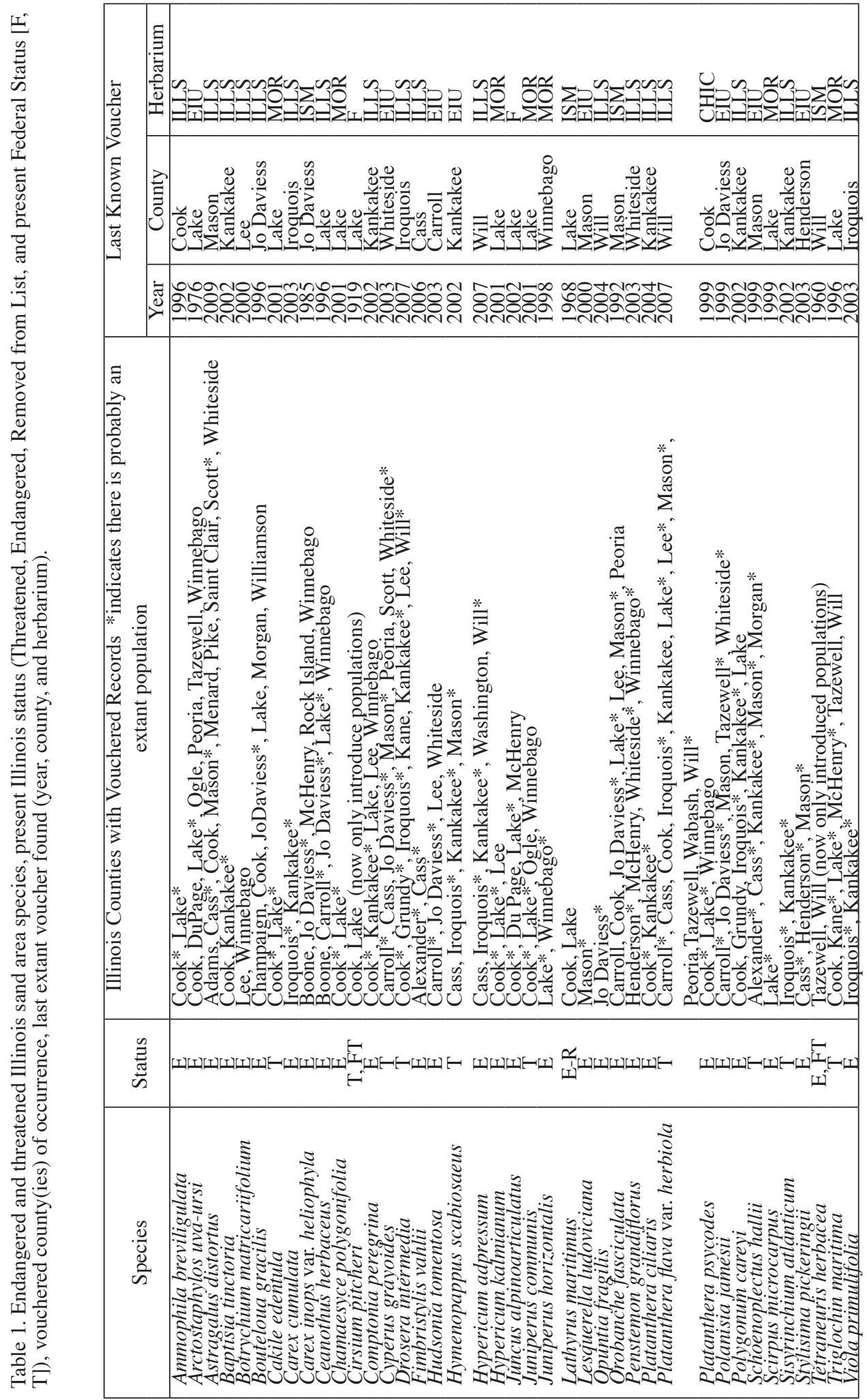


in this paper could allow rare plant conservation in Illinois to become more proactive by encouraging the selection of locations by state, local, and nongovernment organizations where in situ conservation could be conducted once population sizes and, if possible, demographics are known. Such information will allow the evaluation of management activities (e.g., removal of brush, prescribed burns) and their effectiveness. In addition, the information presented in this paper (i.e., distribution and habitat requirements) can encourage research opportunities on population genetics, reproductive ecology, and climate change responses. Lastly, although some funding has been allocated to search for these rare sand species and map their habitats, few resources have been allocated to research activities. This puts into jeopardy the success of Illinois' rare plant conservation programs, because without these research activities, the development of such conservation efforts are hindered.

\section{FERN AND FERN ALLIES}

\section{OPHIOGLOSSACEAE}

Botrychium matricariifolium (Doll.) A. Br. (daisyleaf grape fern, daisy-leaved moonwort) Specimens: Lee (ILLS), Winnebago (ILLS). Status: Listed as Endangered in 1980.

Botrychium matricariifolium, a species of old fields, second growth forests, and other disturbed sites in the northeastern United States and adjacent Canada, extends from Virginia north to Newfoundland and west through the Great Lakes to Minnesota (Wagner, Jr. and Wagner 1993). Daisyleaf grape fern was first collected in Illinois at Rock Cut State Park in the Winnebago Drift Section of the Northeastern Morainal Natural Division, but the state park no longer supports a population. A second Winnebago County population found in a successional sand forest near Colored Sands Bluff Nature Preserve has not been observed since 1993 (not a vouchered location). Daisyleaf grape fern was recently discovered in the Green River Lowland Section of the Grand Prairie Natural Division [Lee Co., edge of dry-mesic sand prairie, Green River State Conservation
Area, 13 Jun 2000, L.R. Phillippe, J.E. Ebinger \& W.C. Handel 31666 (ILLS)]. Recent attempts to relocate this species in Lee County were not successful and the daisyleaf grape fern may be extirpated from Illinois.

Illinois Collections: [Winnebago Co., Rock Cut State Park, 15 Jun 1970, M. Jones \& D. McFall s.n. (ILLS)].

Illinois Literature: McFall and Jones (1972), Mohlenbrock (1999a), Herkert and Ebinger (2002), Phillippe et al. (2003b).

\section{GYMNOSPERMS}

\section{CUPRESSACEAE}

Juniperus communis L. (ground juniper)

Specimens: Cook (F, ILLS, ISM, MOR), Lake (F, ILL, ILLS, ISM, MOR, MWI), Ogle (ISM), Winnebago (MOR).

Status: Listed as Threatened in 1980.

The geographic range of the circumpolar Juniperus communis extends from the subartic and boreal regions of Alaska and Canada into the northern parts of the United States, particularly around the Great Lakes, New England, and in the Rocky and Appalachian mountains. Ground juniper is a species of dunes and adjacent glacial till bluffs along the shoreline of Lake Michigan in the Northeastern Morainal Natural Division of Cook and Lake counties. Many collections of this species are from Illinois Beach State Park. Habitat degradation, due to recreational use and shoreline erosion, is a major habitat concern for ground juniper. Cultivars of this species are used for landscaping and sometimes these cultivars escape. Most Illinois collections of ground juniper, other than those found along the lake shore, are cultivated or adventive. Exceptions may be an Ogle County collection [sandy woods, Sinissippi Forest, 6 Jul 1969, D.R. Wade \& D.E. Wade C-2039 (ISM), and a Winnebago County collection [edge of a limestone cliff, Blackhawk Spring Forest Preserve, 7 Jun 1991, M.D. Jones 192 (MOR)].

Illinois Collections: [Cook Co., Chicago, Jun 1859, F. Scammon s.n. (F); Lake Co., Lake Forest, Jul 1860, G. Vasey 1 (ISM)].

Illinois Literature: Cowles (1899), Gates 
(1910, 1912), Fuller (1914), Atwell (1932), Tehon (1942), Ross (1963), Moran (1978), Adams (1993).

Juniperus horizontalis Moench (trailing juniper)

Specimens: Lake (EIU, DEK, F, ILL, ILLS, ISM, MO, MOR, MWI, RCH, SIU), Winnebago (MOR).

Status: Listed as Endangered in 1980.

The geographic range of Juniperus horizontalis extends from the subartic and boreal regions of Alaska and Canada into the northern parts of the United States particularly around the Great Lakes and northern New England (Adams 1993). It is a common species of the dunes and sandy shores of Lake Michigan in the Lake Michigan Dunes Section of the Northeastern Morainal Natural Division in Lake County. Trailing juniper presently is scattered throughout the foredunes at Illinois Beach Nature Preserve and North Dunes Nature Preserve in Lake County (IDNR Natural Heritage Database 2005). It still persists at both sites, but most populations are threatened by habitat destruction due to human interference, and sometimes by accelerated shoreline erosion. A Winnebago County collection [dry hillside, Atwood Nature Center, 3 miles SW of Rockford, 10 Oct 1998, M. Murphy s.n. (MOR)] may represent a native population.

Illinois Collections: [Lake Co., sand hills, Waukegan, 17 Sep 1898, W.S. Moffatt s.n. (ILL)]. This is the only Illinois specimen we could find of this species collected before the beginning of the twentieth century. A Cook County record reported by Mohlenbrock (2002) and Herkert and Ebinger (2002), was not located by herbaria searches. Collections from outside extreme northern Illinois represent cultivated or adventive individuals.

Illinois Literature: Cowles (1899), Gates (1910, 1912), Pepoon (1927), Atwell (1932), Evers (1963), Tehon (1942), Ross (1963), Evers and Page (1977), Adams (1993).

\section{DICOTS}

\section{ASTERACEAE \\ Cirsium pitcheri (Torr.) Torr. \& Gray (dune}

thistle, Pitcher's thistle)

Specimens: Cook (F, ILL, ILLS, ISM, ISU, MO), Lake (F, ILL).

Status: Listed as Threatened in 1989. Federally threatened.

Dune thistle is endemic to beach and dune habitats around Lake Huron, Lake Michigan, and Lake Superior in Ontario, Michigan, Indiana, Illinois, and Wisconsin (Keil 2006). All Illinois collections are from the Lake Michigan Dunes Section and the Chicago Lake Plain Section of the Northeastern Morainal Natural Division in Cook and Lake counties. Presently, dune thistle is extirpated from Illinois, probably the result of lakeshore erosion, development, and recreational use of its habitat. As this species was originally associated with early and mid-successional blowouts on the high dunes adjacent to Lake Michigan, attempts were made to reintroduce dune thistle on two sites at Illinois Beach State Park in 1991 (Bowles et al. 1993). At the present time, this introduction has been successful since a total of 146 dune thistles were found at Illinois Beach State Park in 2007 (Taft et al. 2009). In 2009, this species was introduced at Montrose Beach Dunes, Cook County, by researchers at the Chicago Botanic Garden. Presently, no native populations of this species are known to occur in Illinois, the species being extirpated from the state (Ebinger et al. 2010).

Illinois Collections: [Cook Co., near Chicago, 13 Jun 1862, G. Vasey s.n. (F); Lake Co., along the shores of Lake Michigan, Waukegan, 20 Jul 1919, H.C. Benke 2707 (F)]. In Illinois the dune thistle had been fairly commonly collected between 1862 and 1919. This species has not been collected since 1919 .

Illinois Literature: Warne (1870), Cowles (1899), Hill (1910), Gates (1912), Fuller (1925), Atwell (1932), Guire and Voss (1963), Bowles (1991b), McEachern (1992).

Hymenopappus scabiosaeus L'Her. (old plainsman)

Specimens: Cass (F, ILL, MO), Iroquois (EIU, ILL, ILLS, ISM, MOR), Kankakee (EIU, F, ILL, ILLS, ISM, MOR, SIU), Mason (EIU, F, ILL, ILLS, ISM, KNOX, MOR, MWI, SIU).

Status: Listed as Threatened in 2004. 
Hymenopappus scabiosaeus is a common species of the prairies and plains of the southcentral and southeastern United States, with a geographic range extending from Florida to Alabama and north to Illinois and Indiana (Strother 2006). Old plainsman is known historically from sand prairies and open sand forests of the Illinois River sand deposits of Cass and Mason counties, and from the Kankakee sand deposits in Iroquois and Kankakee counties. McClain and Ebinger (2002) reported that old plainsman was intolerant of competition, being rarely found in sand prairies and open sand forest, and was mostly found in disturbed habitats such as roadsides, degraded sand prairies, and recently abandoned sandy fields. Presently, 16 populations of old plainsman are known from the state, the vouchers were collected in 2001 and 2002 (EIU).

Illinois Collections: [Cass Co., Beardstown, 1842, A. Geyer s.n. (MO)]. Only two subsequent collections are known from Cass County [10 Jun 1846, S.B. Mead s.n. (ILL); 23 May 1856, E. Hall s.n. (F)]. There is one early collection from Mason County [sandy barrens, 18 Jun 1845, S.B. Mead s.n. (F, KNOX)].

Illinois Literature: Mead (1846), Tehon (1942), Turner (1956), Wunderlin (1971), Great Plains Flora Association (1986), Phillippe et al. (2002a, 2002b, 2003a).

Tetraneuris herbacea Greene (lakeside daisy, four-nerved starflower)

Specimens: Tazewell (EIU, ISM), Will (F, ILL, ILLS, ISM, SIU).

Status: Listed as Endangered in 1980. Federally threatened.

Lakeside daisy is known from the Great Lakes region from Illinois to Ohio and southern Ontario, with a native population at Marblehead Peninsula in Ohio. In Will County, lakeside daisy was abundant and widespread in dry gravel and dolomite prairies within a short stretch of the Des Plaines River near Joliet in the Morainal Section of the Northeastern Morainal Natural Division. The species declined with habitat loss and the last population was destroyed in 1981 (DeMauro 1990). Voss
(1935) reported many plants of lakeside daisy at Manito Prairie Nature Preserve, Tazewell County, in the Illinois River sand deposits. By the early 1960 s this species had disappeared from the site probably due to grazing and fire suppression (Wunderlin 1971). This species has been reintroduced into Manito Prairie Nature Preserve in Tazewell County, and Lockport Prairie Nature Preserve and Romeoville Prairie Nature Preserve in Will County (McClain et al. 2004a). In 2007, some individuals of lakeside daisy persisted at all re-introduction locations (Taft et al. 2009). Presently, no native populations of this species are known to occur in Illinois, the species being extirpated from the state (Ebinger et al. 2010).

Illinois Collections: [Will Co., dry gravelly bank of canal, Joliet, 9 May 1902, E.J .Hill 32 (F); Tazewell Co., sandy bluff, 6 miles $\mathrm{N}$ of Manito, May 1934, J. Voss 15682 (ISM)]. A Mason County record reported by Mohlenbrock (2002) and a Du Page County record reported by Herkert and Ebinger (2002) could not be confirmed by herbaria searches.

Illinois Literature: Gray (1867), Clute (1904, 1931, 1946), DeMauro (1990, 1993, 1994), Cusick (1991), Moràn-Palma and Snow (1997), Bierner and Turner 2006).

\section{BRASSICACEAE}

Cakile edentula (Bigel.) Hook. (sea rocket)

Specimens: Cook (F, ILL, ILLS, ISM, ISU, MO, MOR, SIU), Lake (F, DEK, EIU, ILL, ILLS, ISM, MOR, MWI, SIU).

Status: Listed as Threatened in 1980.

Sea rocket is found along the Atlantic coast from Labrador to South Carolina and inland around the Great Lakes. In Illinois, sea rocket is a shoreline species of open sandy beaches of Lake Michigan in the Northeastern Morainal Natural Division in Cook and Lake counties. Most sightings are from private beaches and city parks, but populations presently occur at Illinois Beach Nature Preserve and North Dunes Nature Preserve. Nearly all populations are threatened by habitat destruction due to human interference, off-road vehicles, and accelerated shoreline erosion. The first habitat description for this taxon in Illinois was the 
lakeshore of Lake Michigan in Cook County, almost within the water's spray with Argentina anserina, Chamaesyce polygonifolia, and Corispermum hyssopifolium (Warne 1870). Illinois Collections: [Cook Co., lake shore, Chicago, Jul-Aug 1860, F. Scammon s.n. (F); Lake Co., beach, Waukegan, 18 Aug 1906, H.A. Gleason \& F.D. Shobe 359 (ILL)]. We have located 21 specimens that were collected before 1900, all from Cook County.

Illinois Literature: Vasey (1861a, 1870), Cowles (1899), Gates (1912), Fuller (1925), Atwell (1932), Evers (1963), Guire and Voss (1963), Evers and Page (1977), Keddy (1982), Swink and Wilhelm (1994), Greenberg and Milde (1994), Fant et al. (2008).

Lesquerella ludoviciana (Nutt.) S. Wats. (silvery bladderpod)

Specimens: Mason (EIU, ILL, I LLS, ISM).

Status: Listed as Endangered in 1980.

First reported from Illinois by Gleason (1910), the silvery bladderpod is a common species of the short and mixed grass prairies of the central United States and adjacent Canada, with scattered populations into eastern Minnesota. The Illinois site is at the Henry Allan Gleason Nature Preserve, Mason County, in the Illinois River and Mississippi River Sand Area Natural Division. This locality is disjunct hundreds of km east of the species' normal range. This relict population probably became established in Illinois during the hypsothermal period after Wisconsian glaciation when the climate was drier and warmer. In sand prairie blowouts, the conditions appear to be ideal for the continued existence of the silvery bladderpod. Presently, three populations of silvery bladderpod are known to occur in the preserve (McClain et al. 2005).

Illinois Collections: [Mason Co., bunchgrass formation on sand-dunes, 22 Aug 1904, H.A. Gleason s.n. (IND, ILLS); Mason Co., blowout, 3 miles N of Topeka, 21 Jun 1961, R.A. Evers 69432 (ILLS)].

Illinois Literature: Hart and Gleason (1907), Payson (1921), Maier (1976), Evers and Page (1977), Mohlenbrock (1980), Rollins (1993).

\section{CACTACEAE}

Opuntia fragilis (Nutt.) Haw. (fragile prickly pear, little prickly pear)

Specimen: Jo Daviess (EIU, ILL, ILLS, ISM, MWI).

Status: Listed as Endangered in 1989.

Little prickly pear is a common species of the dry prairies and plains in the westcentral United States and adjacent Canada, with scattered populations to the east along Lake Superior and the sandy terraces of the northern Mississippi River valley in Illinois and Wisconsin (Pinkava 2003). These localities are disjunct hundreds of kms east of the species' normal range. Gleason (1910) reported this species from Jo Daviess County, where it occurs in natural to disturbed dry sand prairie. In 1986, the little prickly pear was rediscovered at the original collected site where it is probably a relict population that entered Illinois during the hypsothermal period after the Wisconsian glaciation when the climate was drier and warmer. Extensive populations of this cactus are still present within the Lost Mound Unit, Upper Mississippi River National Wildlife and Fish Refuge in the Mississippi River Section of the Illinois River and Mississippi River Sand Areas Natural Division. Illinois Collections: [Jo Daviess Co. bunchgrass association, Hanover, 18 Aug 1908, H.A. Gleason s.n. (GH, ILL)].

Illinois Literature: Gleason (1922), Sheviak (1979), Schwegman (1991), Robertson et al. (1997), Ribbens and Anderson (2008).

\section{CAPPARACEAE}

Polanisia jamesii (Torr. \& Gray) Iltis (James' clammyweed)

Specimens: Carroll (ILLS), Jo Daviess (EIU, ILL, ILLS, ISM), Mason (ILL, ILLS, ISM, MO, MWI, SIU), Tazewell (ILLS, ISM), Whiteside (EIU, ILL, ILLS, ISM, ISU, MOR).

Status: Listed as Threatened in 1980, changed to Endangered in 1989.

The geographic range of James' clammyweed includes the Great Plains, from Texas north to Colorado, South Dakota, and Wisconsin, and east to Illinois. Found in blowing sand and blowouts of dry sand prairies, this species 
is limited in Illinois to the Illinois River and Mississippi River Sand Areas Natural Division. This species was commonly collected from the Illinois River Section in Mason and Tazewell counties during the 1960s but may now be extirpated there. The most recent collection [Tazewell Co., disturbed sand, Malone, $16 \mathrm{Sep}$ 1997, S.R. Hill 29764 (ILLS)] may still persist. In the Mississippi River Section, this species is known from Carroll, Jo Daviess, and Whiteside counties. This species is relatively common at the Lost Mound Unit, Upper Mississippi River National Wildlife and Fish Refuge (IDNR Natural Heritage Database 2005) where it is most commonly found in blowouts and areas of blowing sand.

Illinois Collections: [Mason Co., blowouts, Havana, 18 Aug 1904, H.A. Gleason s.n. (MO); Jo Daviess Co, blowouts, Hanover, 17 Jun 1908, H.A. Gleason \& F.C. Gates 2640 (ILL); Tazewell Co., SW of Green Valley, 24 Jul 1962, R.A. Evers 74956 (ILLS)].

Illinois Literature: Hart and Gleason (1907), Gleason (1910, 1922), Gleason and Gates (1912), Vestal (1913), Evers and Page (1977), Schwegman (1991), Robertson et al. (1997).

\section{CISTACEAE}

Hudsonia tomentosa Nutt. (false heather, beach heather)

Specimens: Carroll (EIU, ILLS, ISM), Jo Daviess (ILL, ILLS, ISM, MOR, SIU), Lee (KNOX, ILL, ISM, ISU), Whiteside (EIU, ISM).

Status: Listed as Endangered in 1980.

Beach heather grows on and about coastal dunes from Maine to North Carolina, inland in Canada from Labrador to Manitoba, and in the northeastern United States from West Virginia to Wisconsin and Minnesota. The dry sand prairie habitat of this species may eliminate competition, particularly in blowing sand and blowouts. This species has been collected in the Mississippi River Section of the Illinois River and Mississippi River Sand Areas Natural Division in Carroll, Jo Daviess, and Whiteside counties and in the Green River Lowland Section of the Grand Prairie Natural Division in Lee County. The Lee County specimen is from a degraded dry-mesic sand prairie in a pine plantation and has not been relocated. Beach heather is still common in Illinois, many populations occurring at the Lost Mound Unit, Upper Mississippi River National Wildlife and Fish Refuge in Jo Daviess County.

Illinois Collections: [Lee Co., sand hills, Dixon, 27 Sep 1882, A.B. Seymour 14714 (ILL); Jo Daviess Co., blowout near Hanover, 13 Jun 1908, H.A. Gleason \& F.C. Gates 2536 (ILL); Carroll Co., sand prairie, S of Savanna, 12 May 1955, R.A. Evers 46301 (ILLS)]. A Fulton County record reported by Mohlenbrock (2002) has not been confirmed by herbarium searches. Illinois Literature: Cowles (1899), Gleason (1910), Tehon (1942), Mohlenbrock (1978), Gleason and Cronquist (1991), Bowles and Jones (1991, 1995), Ebinger et al. (2006).

\section{CONVOLVULACEAE}

Stylisma pickeringii (Torr.) Gray var. pattersonii (Fern. \& Schub.) Myint (Patterson's bindweed)

Specimens: Cass (EIU, ILL, ILLS, ISM, MOR, MWI), Henderson (EIU, KNOX, ILL, ILLS, ISU), Mason (EIU, ILL, ILLS, ISM, MWI, SIU).

Status: Listed as Threatened in 1980, changed to Endangered in 1994.

Stylisma pickeringii is a species of the dry barrens of the coastal plain of New Jersey south to Florida and Alabama (var. pickeringii), and in dry sand prairies of Illinois, Iowa, Kansas, Oklahoma, and Texas (var. pattersonii). The first published record for Patterson's bindweed in Illinois was from its type locality four miles north of Oquawka (Patterson 1874, 1876). This site is located on state land in the Big River State Forest in Henderson County. All collections are from the Illinois River and Mississippi River Sand Areas Natural Division and most are from blowouts and dry sand prairies, but occasionally are associated with fallow sandy fields and pine plantations. Most known populations have been observed within the past few years and have numerous individuals.

Illinois Collections: [Henderson Co., near Oquawka, 4 Oct 1872, H.N. Patterson s.n. (KNOX)]. In the Illinois River sand deposits 
Patterson's bindweed grows on private land. [Cass Co., sand prairie 4 miles S of Beardstown, 16 Sep 1953, R.A. Evers 41102 (ILLS); Mason Co., sand prairie, several miles W of Saidora, 4 Jul 1954, R.T. Rexroat \& G.S. Winterringer 11589 (ISM)].

Illinois Literature: Gleason (1910), Fernald and Schubert (1949), Jones (1952), Jones and Fuller (1955), Mohlenbrock (1982a), Todd et al. (2002).

\section{DROSERACEAE}

Drosera intermedia Hayne (narrow-leaved sundew)

Specimens: Cook (EIU, F, ILL, ILLS, ISM, MOR), Grundy (ILLS), Iroquois (EIU, ILLS, ISM, MOR), Kane (ILLS, MOR), Kankakee (ILL, ILLS), Lee (ILL, ILLS, ISM), Will (ILLS, MOR).

Status: Listed as Threatened in 1980.

This insectivorous species occurs in the northeastern United States and adjacent Canada. Many early collections are known from Cook County along with a few from Kane County, all in the Northeastern Morainal Natural Division. Narrow-leaved sundew was collected in the Green River Lowland Section of the Grand Prairie Natural Division as recently as 1990 [Lee Co., wet sand, "Five Points", 23 Jul 1990, J. Long 1176 (ILL)], but not relocated. This species is common in the Kankakee sand deposits in Grundy, Iroquois, Kankakee, and Will counties. There are recent observations from Jurgensen Woods Nature Preserve in Cook County, Goose Lake Prairie Nature Preserve in Grundy County, Iroquois County Conservation Area, Leesville Savanna Natural Area and Sweet Fern Savanna Natural Area in Kankakee County, and Braidwood Dunes and Savanna Nature Preserve and Sand Ridge Savanna Nature Preserve in Will County (IDNR Natural Heritage Database 2005, 2009).

Illinois Collections: [Cook Co., near Lake Michigan, Thornton, Sep 1866, E.J. Hill s.n. (ILL); Kankakee Co., sand near Kankakee, 25 Jul 1873, E.J. Hill 294 (ILL)]. Lake, McHenry, and Ogle county records reported by Mohlenbrock (2002) could not be confirmed by herbaria searches.
Illinois Literature: Pepoon (1927), Clute (1931), Wayne (1944), Duerr (1967), Bowles (1991a), Phillippe et al. (2002a, 2002b).

\section{ERICACEAE}

Arctostaphylos uva-ursi (L.) Spreng. (bearberry, hog-cranberry, kinnikinnick)

Specimens: Cook (F, ILL, ISU, MO), Du Page (F), Lake (DEK, EIU, F, ILL, ILLS, ISM, MOR, MWI, NLI, SIU), Ogle (ISM, NLI), Peoria (F, ILL), Tazewell (ILL), Winnebago (ILL, ISM, NLI).

Status: Listed as Endangered in 1980.

Arctostaphylos uva-ursi has a circumpolar distribution, occurring throughout Canada and the northern United States, and south into the Appalachian Mountains to Virginia. In Illinois, common bearberry is now restricted to the dunes on beaches of Lake Michigan in the Northeastern Morainal Natural Division where it has been reported from the Illinois Beach Nature Preserve and the North Dunes Nature Preserve (IDNR Natural Heritage Database 2005, 2009). Most sightings are of plants scattered throughout the foredunes. No specimens have been collected in Cook County since 1897. Common bearberry is historically known from open sandy wooded bluffs in Ogle, Peoria, Tazewell, and Winnebago counties but these populations are probably extirpated (Herkert and Ebinger 2002).

Illinois Collections: [Cook Co., lakeshore, Chicago, Aug 1859, F. Scammon s.n. (F); Lake Co., sand dune, N of Waukegan, 8 Jun 1908, F.C. Gates 2491 (ILL)]. Twenty specimens collected prior to 1900 have been located. Only a few recent sightings of this species have been made (IDNR Natural Heritage Database 2005, 2009).

Illinois Literature: Vasey (1861a), Warne (1870), Cowles (1899), Gates (1912), Fuller (1934), Tehon (1942), Fell (1957), Evers (1963), Ross (1963), Evers and Page (1977), Mohlenbrock (1978), Anderson and Ugent (1980), Gleason and Cronquist (1991).

\section{EUPHORBIACEAE}

Chamaesyce polygonifolia (L.) Small (seaside spurge) 
Specimens: Cook (F, ILL, ILLS, ISM, ISU, MOR, SIU), Lake (EIU, F, ILL, ILLS, ISM, MOR).

Status: Listed as an Endangered in 1980.

Seaside spurge is a common species of the Atlantic coast from Quebec to Georgia, and along the southern part of the Great Lakes. In Illinois, seaside spurge is a shoreline species of open sand beaches of Lake Michigan. All herbarium specimens found give the habitat as sandy lakeshore, dunes, beaches, or upper beaches, and are from the Northeastern Morainal Natural Division in Cook and Lake counties. Most sightings of this species are plants scattered throughout the beach and foredunes at Illinois Beach Nature Preserve and North Dunes Nature Preserve where seaside spurge is still relatively common. Most populations are threatened by habitat destruction due to human interference, off-road vehicles, and shoreline erosion.

Illinois Collections: [Cook Co., 17 Aug 1859, F. Scammon s.n. (F); Lake Co., beach, Waukegan, 18 Aug 1906, H.A .Gleason \& F.D. Shobe 336 (ILL)]. There are 29 early collections prior to 1900 that have been located, and nearly 75 Illinois specimens are available for study. A Peoria County record (Herkert and Ebinger 2002) and a Fulton County record (Mohlenbrock 2002) could not been confirmed by herbaria searches.

Illinois Literature: Vasey (1861a, 1870), Warne (1870), Cowles (1899), Gates (1912), Fuller (1925), Atwell (1932), Wheeler (1941), Guire and Voss (1963), Mohlenbrock (1982b), Greenberg and Milde (1994), Swink and Wilhelm (1994).

\section{FABACEAE}

Astragalus distortus Torr. \& Gray (bent milk vetch, Ozark milk vetch)

Specimens: Adams (ILLS), Cass (EIU, F, ILL, ILLS, ISM, MO, MWI), Cook (ILL), Mason (EIU, F, ILL, ILLS, ISM, MO, MWI), Menard (F), Pike, (ILLS, ISM, NLI), St. Clair (ILL), Scott (EIU, ISM, SIU), Whiteside (ILLS, ISM). Status: Listed as Endangered in 2004.

Bent milk vetch is infrequent to locally common in the southeastern Great Plains, from
Texas and Louisiana north to southern Iowa and western Illinois, with outliers in the Appalachian Mountains of West Virginia and Virginia (Isely 1998). It is mostly restricted to disturbed sand prairie remnants and sandy roadsides in Illinois River sand deposits. Extant populations are known only from Cass, Mason, and Scott counties. Based on herbarium records, McClain and Ebinger (2003) found the number of extant populations of bent milk vetch declined from 23 in the 1950 s to only 6 in 2002. Presently, populations are known from Sand Prairie-Scrub Oak Nature Preserve, Barkhausen Woods Conservation Area, Sand Ridge State Forest, and Revis Hill Prairie Nature Preserve.

Illinois Collections: [Mason Co., 18 Jun 1845, S.B. Mead s.n. (F, MO); Cass Co., 12 May 1946, S.B. Mead s.n. (F)]. Bent milk vetch specimens from Cook, Menard, and St. Clair counties were collected in the late 1800s, and may represent cultivated plants. There is insufficient information on the labels to determine their status.

Illinois Literature: Mead (1846), McDonald (1900), Jones and Fuller (1955), Maier (1976), Great Plains Flora Association (1986).

Baptisia tinctoria (L.) R. Br. (yellow wild indigo)

Specimens: Cook (ILL, ISU), Kankakee (ILLS).

Status: Listed as Endangered in 1980, delisted in 1989, listed as Endangered in 2004.

Yellow wild indigo is a common species of the Atlantic coast from southern Maine to Florida, inland to Kentucky and Tennessee, and rare westward into Minnesota, Wisconsin, Michigan, Iowa, Illinois, and Indiana. In Illinois, this species is presently known only from the Kankakee Sand Area Section of the Grand Prairie Natural Division. This species was originally listed as endangered in Illinois (Sheviak 1981) after being observed in a nature preserve in Cook County (no voucher found). Later attempts to relocate this population failed and the species was delisted. In 2002, yellow wild indigo was found in Illinois [Kankakee Co., dry-mesic sand savanna, Leesville Savanna Natural Area, 26 Jul 2002, M.A. Feist 
\& C. Carroll 1900 (ILLS)]. Baptisia x deamii Larisey, a hybrid between $B$. bracteata and $B$. tinctoria, has been found at the same site (Carroll and Feist 2004).

Illinois Collections: The first Illinois collection of Baptisia tinctoria is from the herbarium of R.H. Ward in 1857 (ILL), but specific locality information was not given. A Winnebago County record reported by Fernald (1940) could not be confirmed by herbaria searches. Illinois Literature: Brendel (1859), Higley and Raddin (1891), Larisey (1940), Gleason and Cronquist (1991), Phillippe et al. (2003a).

Lathyrus maritimus (L.) Bigel. (beach pea) Specimens: Cook (F, ILL, ISM, ISU, MO, SIU), Lake (F, ILL, ISM, MO).

Status: Listed as Endangered in 1980, delisted in 2009. Presently considered extirpated in Illinois (Ebinger et al. 2010).

Synonyms: Lathyrus maritimus (L.) Bigel. var. glaber Ser., Lathyrus japonicus Willd. var. glaber (Ser.) Fern., Lathyrus japonicus Willd. var. maritimus (L.) Kartesz and Gandhi.

A sandy shoreline species, the beach pea is found along the Atlantic coast from New Jersey north to Canada and inland to the Great Lakes. In Illinois, this species was restricted to the Northeastern Morainal Division in Cook and Lake counties. Formerly common, this taxon has not been collected in Illinois since 1968 [Lake Co., Illinois Beach State Park, 1 Aug 1968, G.S. Winterringer 24100 (ISM)], and has not been seen since 1977 (Bowles et al. 1991). Erosion from high lake levels has severely affected the habitat of beach pea, which is probably extirpated from the state. No populations of beach pea have been recorded by the IDNR Natural Heritage Database (2005).

Illinois Collections: [Cook Co., Chicago, 1860, F. Scammon s.n. (F)]. Prior to 1900 we have located 17 specimens, nearly all from Cook County.

Illinois Literature: Vasey (1861a), Warne (1870), Cowles (1899), Gates (1912), Fuller (1925), Atwell (1932), Gambill, Jr. (1953), Fassett (1961), Guire and Voss (1963), Swink and Wilhelm (1994).

\section{HYPERICACEAE}

Hypericum adpressum Bart. (shore St. John'swort, creeping St. John's-wort)

Specimens: Cass (ISM), Iroquois (EIU, ILLS, ISM), Kankakee (F, ILLS), Washington (EIU), Will (F, ISM, MOR).

Status: Listed as Endangered in 1980.

Hypericum adpressum is a relatively rare species in much of the eastern United States from Massachusetts south to Georgia and occasionally inland through Tennessee to Indiana and Illinois. In Illinois, this taxon is mostly restricted to the Kankakee Sand Area Section of the Grand Prairie Natural Division. Most collections are from the Iroquois County Conservation Area and the Hooper Branch Savanna Nature Preserve in Iroquois County, from Leesville Savanna Natural Area and Sweet Fern Savanna Land Water Reserve in Kankakee County, and Braidwood Dunes and Savanna Nature Preserve and Sand Ridge Savanna Nature Preserve in Will County. This species is rare in the Illinois River sand deposits [Cass Co., open sand, Shick Shack Sand Pond Nature Preserve, 25 Jun 1985, J.E. Schwegman s.n. (ISM)]. A specimen of shore St. John's-wort from Washington County appears to be correctly identified [Venedy pin oak swamp and flatwoods, 18 Jul 2001, J.E. Ebinger 30150 (EIU)], but has not been relocated.

Illinois Collections: [Kankakee Co., moist sand prairie, Kankakee, 6 Jul 1871, E.J. Hill 87 (F)]. Other collections are mostly from the late 1900 s, and we have found some populations that contain numerous individuals, particularly in Will County.

Illinois Literature: Mohlenbrock (1978), Schwegman (1991), Phillippe et al. (2002a, 2002b).

Hypericum kalmianum L. (Kalm's St. John'swort)

Specimens: Cook (F, ILL, ILLS, ISM, ISU, MO, MWI), Lake (DEK, EIU, F, ILL, ILLS, ISM, MOR, MWI, SIU), Lee (ILL, ISM).

Status: Listed as Endangered in 1980.

Hypericum kalmianum is a relatively common species of the Great Lakes region occurring around Lakes Erie, Huron, and Michigan, 
and sporadically inland from Quebec to western Ontario, and from western New York, and the northern parts of Ohio, Indiana, and Illinois, to central Wisconsin. Occasionally cultivated, Kalm's St. John's-wort is mostly a shoreline species of open dunes and swales on Lake Michigan beaches in the Northeastern Morainal Natural Division of Cook and Lake counties. In Cook County, Kalm's St. John's-wort has been found at Thornton-Lansing Road Nature Preserve and Jurgensen Woods Nature Preserve. The Lake County populations are mostly from Illinois Beach Nature Preserve, Lyons Prairie and Marsh Nature Preserve, and Spring Bluff Nature Preserve. This species has been reported from a sandy depression in Lee County but has not been relocated [May Twp., Sect. 31, 29 Jun 1990, J.W. Long 1168 (ILL)].

Illinois Collections: [Cook Co., Chicago, 15 Jul 1859, F. Scammon 30134 (F); Lake Co., Waukegan, 25 Jul 1916, H.C. Benke 1289 (F)]. There are about 20 early collections prior to 1900 that have been located, all from Cook County.

Illinois Literature: Warne (1870), Hill (1890, 1899a), Cowles (1899), Fuller (1925), Guire and Voss (1963), Mohlenbrock (1978), Swink and Wilhelm (1994).

\section{MYRICACEAE}

Comptonia peregrina (L.) Coult. (sweetfern) Specimens: Cook (EIU, F, ILL, ILLS, ISM, MOR, MWI), Kankakee (ILL, ILLS, ISM), Lake (F, ILLS), Lee (ILL, ILLS, ISM), Winnebago (DEK, F, ILL, ILLS, ISM, MO, NLI). Status: Listed as Endangered in 1980.

Sweetfern is found throughout much of the northeastern United States and adjacent Canada, from Prince Edward Island to North Carolina, and west through the Great Lakes (Bornstein 1997). It grows in sand prairies and sand savannas and is relatively rare in the Northeastern Morainal Natural Division in Cook, Lake, and Winnebago counties. It was seen in 2008 at Thornton-Lansing Road Nature Preserve and the Jurgenson Woods Nature Preserve in Cook County, and was collected in the Green River Lowland Section of the Grand Prairie Natural Division [Lee Co., dry woods,
25 Jul 1954, J. Long 69 (ILLS)], but not relocated. More collections are from the Kankakee Sand Area Section of the Grand Prairie Natural Division in Kankakee County [Hopkins Park, 24 Sep 1916, W. Trelease s.n. (ILL)]. The Winnebago County sweetfern population [sandy hillside, near Mintz Road S of Rock Cut, 11 Apr 1956, E.W. Fell 56-5 (DEK)] is extirpated (Kieninger 2009b).

Illinois Collections: [Cook Co., Glencoe, 6 Aug 1873, P. Blatchford 2522 (ISM)]. A Will County record reported by Herkert and Ebinger (2002) could not be confirmed by herbaria searches.

Illinois Literature: Warne (1870), Babcock (1872), Higley and Raddin (1891), Tehon (1942), Fell (1955), Swink and Wilhelm (1994), Phillippe et al. (2003a).

\section{OROBANCHACEAE}

Orobanche fasciculata Nutt. (clustered broomrape)

Specimens: Carroll (ISM), Cook (F), Jo Daviess (ILL), Lake (F, ISM, MOR), Lee (F, ISM, ISU, MO), Mason (ISM, MWI), Peoria (ILL, ISM).

Status: Listed as Endangered in 1980.

The root parasite Orobanche fasciculata occurs in western boreal Canada, extending south from the Yukon to Baja California and east to Texas, Indiana, and Michigan. Early collections are mostly from Lake Michigan beaches and this species is presently known from North Dunes Nature Preserve and Illinois Beach Nature Preserve. In the Illinois River and Mississippi River Sand Areas Natural Division, clustered broomrape was reported from Jo Daviess County by Gleason (1910), and in the Illinois River Section it was collected in 1992 [Mason Co., Revis Hill Prairie, 25 May 1992, F. Catchpole s.n. (ISM)], and was observed in 2000. Also, not relocated was a collection from Peoria County [Horse Shoe Bottom overlook, 27 May 1922, V.H. Chase 3896 (ILL)]. Only old collections are known from Lee County [sandy fields near Dixon, 1860, G. Vasey 14958 (ISM)] and Carroll County [river bluff, $10 \mathrm{Jul}$ 1909, H.C. Cowles s.n. (ISM)].

Illinois Collections: [Cook Co., Cleaverville, 5 
Jun 1860, F. Scammon s.n. (F); Lake Co., sandy bank, Waukegan, 25 Jun 1927, N.V. Haynie s.n. (F)]. A Henry County record reported by Herkert and Ebinger (2002) could not be confirmed by herbaria searches.

Illinois Literature: Cowles (1899), Gates (1912), Munz (1930), Guire and Voss (1963), Great Plains Flora Association (1986). The closely related and endangered Orobanche ludoviciana Nutt. was not included in this study as it is most commonly associated with river sands in the central part of Illinois.

\section{POLYGONACEAE}

Polygonum careyi Olney (Carey's heartsease) Specimens: Cook (F, MOR), Grundy (ILLS), Iroquois (EIU, ILLS, ISM), Kankakee (ILL, ILLS, ISM, MO), Lake (F).

Status: Listed as Endangered in 1980.

Synonym: Persicaria careyi (Olney) Greene Carey's heartsease is relatively common in northeastern United States and adjacent Canada from Maine to Wisconsin and south to Illinois, Indiana, and Delaware. In Illinois, Polygonum careyi is mostly restricted to wet sand prairies and sand flatwoods of the Kankakee Sand Area Section of the Grand Prairie Natural Division in Grundy, Iroquois, and Kankakee counties. The Iroquois County populations were mostly from Iroquois County Conservation Area and Hooper Branch Nature Preserve, the Kankakee County populations from Miskoda, Tallmadge Sand Forest, and Sweet Fern Savanna Land and Water Reserves. Nearly all of these populations were observed between 2000 and 2006. Carey's heartsease has also been collected from Jurgensen Woods Nature Preserve [Cook Co., barren depression, Zanders Woods, 23 Aug 1986, K. Dritz 500 (MOR)], in the Northeastern Morainal Natural Division. Early collections from Grundy County [Goose Lake area, 9 Sep 1966, R.A. Evers 88284 (ILLS)], and from Lake County [beach, 18 Aug 1928, N.V. Haynie $1137(\mathrm{~F})]$ have been located.

Illinois Collections: [Cook Co., shady swamps, Ravenwood, 6 Aug 1887, R.N. Lloyd s.n. (F); Kankakee Co., 3 miles SE of Hopkins Park, 30 Jul 1937, R.A. Schneider 646 (ILL)].

Illinois Literature: Pepoon (1927), Mohlen- brock and Thomson, Jr. (1987), Swink and Wilhelm (1994), Phillippe et al. (2002a, 2002b, 2003a).

\section{RHAMNACEAE}

Ceanothus herbaceus Raf. (redroot, prairie redroot)

Specimens: Boone (NLI), Carroll (ILLS), Jo Daviess (EIU, ILL, ILLS), Lake (F, ILL, ILLS, MO, MOR, MWI, SIU), Winnebago (DEK, ILL, ILLS, MO, NLI, RCH).

Status: Listed as Endangered in 1980.

Synonyms: Ceanothus ovatus Desf.

Redroot is found at scattered localities in the northeastern United States (Vermont, New York) and adjacent Canada (Quebec), and the central United States from Michigan, Minnesota, and eastern Montana south to Texas. This species has been collected in the Illinois River and Mississippi River Sand Areas Natural Division in Carroll and Jo Daviess counties, and from Northeastern Morainal Natural Division in Boone, Lake, and Winnebago counties. In Illinois, redroot is a common dry sand prairie and black oak sand savanna species (Gates 1912), and is fire adapted and grazing resistant (Bowles and Jones 1995). It is common at the Lost Mound Unit, Upper Mississippi River National Wildlife and Fish Refuge (Ebinger et al. 2006).

Illinois Collections: [Lake Co., Waukegan, 22 Jun 1905, E.J. Hill 79.1905 (ILL); Jo Daviess Co., sand near Blanding, 18 Jun 1948, R.A. Evers 10549 (ILLS); Winnebago Co., gravel prairie E of Rockford, 11 Sep 1948, E.W. Fell \& G.B. Fell 48-373 (ILL)]. Cook, Ogle, and Whiteside county records reported by Herkert and Ebinger (2002) and Mohlenbrock (2002) could not be confirmed by herbaria searches. Illinois Literature: Bebb (1859), Brendel (1859), Gleason (1909, 1910), Pepoon (1927), Tehon (1942), Fuller et al. (1949), Fell (1955), Fell and Fell (1956), Beattie and Culver (1977), Mohlenbrock (1982b), Jones (1994).

\section{SCROPHULARIACEAE}

Penstemon grandiflorus Nutt. (large-flowered beard tongue)

Specimens: Henderson (KNOX, ILL, ILLS, 
ISM, MO, RCH, SIU), McHenry (ILLS, MOR, SIU), Whiteside (ILLS, ISM), Winnebago (ILLS).

Status: Listed as Endangered in 1981.

Large-flowered beard tongue grows in the Great Plains of the central United States from Texas north to Wyoming, North Dakota, and Wisconsin, and east into Illinois. The Illinois populations are probably relicts that entered Illinois during the hypsothermal period after Wisconsian glaciation when the climate was drier and warmer. This species was found recently in mature dry sand prairies at ThomsonFulton Sand Prairie Nature Preserve in Whiteside County, and Ellison Creek Prairie Natural Area and Big River State Forest in Henderson County in the Mississippi River sand deposits (Ebinger et al. 2006). It was also found in Winnebago County [dry prairie, Wilson Prairie Nature Preserve, 1972, D. McFall s.n. (ILLS)] where 120 plants were seen in 1994. The large-flowered beard tongue population from McHenry County found by Swink (1969) was naturalized from farther west and is now extirpated (Swink and Wilhelm 1979).

Illinois Collections: [Henderson Co., prairies, 20 May 1871, H.N. Patterson s.n. (KNOX, $\mathrm{RCH}$ ); Whiteside Co., sand prairie $\mathrm{N}$ of Fulton, 27 May 1970, R.A. Evers 102175 (ILLS)].

Illinois Literature: Patterson (1874, 1876), Gleason (1910), Pennell (1935), Mohlenbrock and Stritch (1985), Great Plains Flora Association (1986), Jones (1994).

\section{VIOLACEAE}

Viola primulifolia L. (primrose violet)

Specimens: Iroquois (EIU, ILLS, ISM, MOR), Kankakee (EIU, F, ILL, ILLS, MOR).

Status: Listed as Endangered in 1980.

Primrose violet is a common species of

the eastern United States and adjacent Canada, occurring from Minnesota east to New Brunswick, south to Florida and Texas and west to Indiana and Oklahoma. Restricted to the Kankakee Sand Area Section of the Grand Prairie Natural Division, the IDNR Natural Heritage Database (2005) reported primrose violet from 15 locations in Iroquois and Kankakee counties. Mostly a disturbance area sand species, some collections were from wet to wet-mesic sand prairies, mesic sand savannas, and sand flatwoods. In Iroquois County, this species is known from the Iroquois County Conservation Area and Hooper Branch Savanna Nature Preserve. The Kankakee County populations were found at Leesville Savanna Natural Area and five Land and Water Reserves, all in Pembroke Township. Nearly all observations have been made since 1998 .

Illinois Collections: [Kankakee Co., swampy ground near Saint Anne, 29 May 1940, G.N. Jones 11449 (ILL); Iroquois Co., mesic sand prairie, Iroquois County Conservation Area, 2 Jun 1982, J. Schwegman 3133 (ISM)]. A Grundy County record (Herkert and Ebinger 2002, Mohlenbrock 2002) could not be confirmed by herbaria searches.

Illinois Literature: Jones and Fuller (1955), Russell (1965), Mohlenbrock (1969), White and Madany (1978), Swink and Wilhlem (1994), Phillippe et al. (2002a, 2002b, 2003a).

\section{MONOCOTS}

\section{CYPERACEAE}

Carex cumulata (L. H. Bailey) Mack. (crowded oval sedge)

Specimens: Iroquois (ILLS), Kankakee (EIU, F, ILLS, MOR).

Status: Listed as Endangered in 1981, delisted in 1989, listed as Endangered in 2004.

Carex cumulata is restricted to the northeastern United States and adjacent Canada, where it is usually found in dry to moist, sandy, and gravelly soil of barrens, acidic woods, and thickets (Mastrogiuseppe et al.2002). All populations of crowded oval sedge in Illinois are from the Kankakee Sand Area Section of the Grand Prairie Natural Division. Collections are from wet sand prairies, oak woodland edges, and occasionally disturbed ground in former crop fields from Iroquois and Kankakee counties. Crowded oval sedge was listed as endangered by Sheviak (1981) and later removed when it was thought to be extirpated. More recently, this species has been collected in Iroquois County [moist sand near pig farm, Beaverville Twp., 6 Jun 1999, A.A. Reznicek 
\& S.A. Reznicek 10836 (ILLS)], and is now known from the Iroquois County Conservation Area and the nearby Hooper Branch Savanna Nature Preserve. In Kankakee County, populations are known from four preserves owned by The Nature Conservancy and the State of Illinois.

Illinois Collections: [Kankakee Co., peaty margin of oak woods, 9 miles E of St. Anne, 27 Jul 1940, R.A. Schneider 1654 (F)].

Illinois Literature: Swink (1969), Swink and Wihlelm (1994), Mohlenbrock (1999b), Philippe et al. (2002a, 2002b, 2003a), Nyboer and Ebinger (2004).

Carex inops L. H. Bailey subsp. heliophila (Mack.) Crins (plains sedge)

Known Specimens: Boone (RCH), Jo Daviess (ISM), McHenry (F, MO), Rock Island (ILL), Winnebago (ILL, NLI, RCH).

Status: Listed as Endangered in 1994.

Synonyms: Carex heliophila Mack.

The geographic range of plains sedge extends throughout the central United States and adjacent Canada, occurring from Montana south to New Mexico, east to Indiana and Michigan, and north into Alberta (Crins and Retting 2002). This species is taxonomically difficult and morphologically very similar to a few other sedge species of similar habitats, particularly Carex pensylvanica Lam. Nearly all collections of this sedge in Illinois were made during the 1950s, the last collection being in 1985 [Jo Daviess Co., sand hill prairie on second bluff, Whitton, 26 Apr 1985, J. Schwegman s.n. (ISM)] in the Wisconsin Driftless Natural Division. Exploring some of the few remaining sand prairies in Jo Daviess and Winnebago counties may locate new populations of this species. Nearly all of the specimens found were annotated as $C$. heliophylla by A.A. Reznicek $(\mathrm{MICH})$ and/or by G.C. Tucker (EIU).

Illinois Collections: [McHenry Co., Cary, 31 May 1935, H.C. Benke 5725 (F, MO); Winnebago Co., dune sand, N of Sugar River Forest Preserve, 21 May 1953, E.W. Fell 53-124 $(\mathrm{RCH})]$. A Hardin County record reported by Mohlenbrock (2002) could not be confirmed by herbaria searches.

Illinois Literature: Rydberg (1932), Fell and
Fell (1956), Fell (1959), Crins and Ball (1983), Schwegman (1991), Mohlenbrock (1999b).

Cyperus grayoides Mohlenbrock (umbrella sedge, Mohlenbrock's sedge)

Specimens: Carroll (ILLS), Cass (ISM, SIU, MWI), Jo Daviess (EIU, ILLS, MOR), Mason (EIU, ILL, ILLS, ISM, MOR, MWI), Peoria (MOR); Scott (ISM, MWI, SIU), Whiteside (EIU, ILLS, MOR).

Status: Listed as Threatened in 1989.

Umbrella sedge is restricted to sand deposits of the Mississippi River Valley from Illinois south to Louisiana and Texas. In Illinois, it is a common species of blowouts and disturbed sand deposits in both sections of the Illinois River and Mississippi River Sand Areas Natural Division (Tucker et al. 2002). In the northern Mississippi River Valley of Illinois, the umbrella sedge is common in Ayers Sand Prairie Nature Preserve, Thomson-Fulton Sand Prairie Nature Preserve, and the Lost Mount Unit (Ebinger et al. 2006). In the Illinois River sand deposits, it is common at Henry Allan Gleason Nature Preserve (McClain et al. 2005), Long Branch Nature Preserve (Phillippe et al. 2004), Matanzas Prairie Nature Preserve (Feist et al. 2008), and Sand Prairie-Scrub Oak Nature Preserve (McClain et al. 2002). Umbrella sedge was found in Peoria County [Peoria, 23 May 1970, R.H. Runde s.n. (MOR)], the specimen being annotated as Cyperus grayoides by R.H. Mohlenbrock in 1992.

Illinois Collections: [Mason Co. bunch grass association, 13 Aug 1903, H.A. Gleason 1047 (ILL); Whiteside Co., sand prairie $\mathrm{N}$ of Fulton, 15 Aug 1952, R.A. Evers 35442 (ILLS)]. Illinois Literature: Mohlenbrock (1959, 2001), Dolbeare (1973), Maier (1976), Schwegman (1990, 1991), Robertson et al. (1997), Yatskievych (1999).

Fimbristylis vahlii (Lam.) Link (Vahl's fimbristylis, Vahl's fimbry)

Specimens: Alexander (ILLS), Cass (EIU, ILL, ILLS, ISM, MOR, SIU).

Status: Listed as Endangered in 1980.

Fimbristylis vahlii is a relatively uncommon species of banks and shores, particularly 
fluctuating ponds in the southern United States and adjacent Mexico, extending as far north as Illinois (Kral 2002). Many disjunct populations of this species probably represent introductions by water birds (McClain et al. 1997), and Vahl's fimbristylis should probably be considered adventive in Illinois. Most collections are from Cass County in the Illinois River and Mississippi River Sand Areas Natural Division where it is sometimes encountered in moist, peaty, sandy soil at the margins of sand ponds and rarely roadside ditches and farm ponds. It is very possible that Vahl's fimbristylis is a recent introduction into Illinois, and has persisted around sand ponds to become an established member of the flora. No populations are known from nature preserves.

Illinois Collections: [Cass Co., mucky peat, W of Virginia, 5 Nov 1959, R.T. Rexroat 6647 (ISM)]. It was collected as recently as 2006 [Cass Co., ephemeral sand pond, Beardstown Marsh Natural Area, 23 Aug 2006, S.R. Hill 37033 (ILLS)]. Vahl's fimbristylis has recently been collected in Alexander County [damp sands of Miller City, 3 Sep 2004, J. Schwegman s.n. (ILLS)]. Schwegman (1984) reported this species from an open sandy marsh SE of Snicarte in Mason County, but no voucher has been located.

Illinois Literature: Kral (1971), Dolbeare (1973), Mohlenbrock (2001).

\section{Schoenoplectus hallii (Gray) S.G. Smith (Hall's bulrush)}

Specimens: Alexander (ILLS), Cass (EIU, ILL, ILLS, ISM, MO, MOR, MWI, SIU), Kankakee (ILL, ILLS, MOR), Mason (EIU, ILL, ILLS, ISM, MO, MOR, MWI), Morgan (ILLS).

Status: Listed as Endangered in 1980, changed to Threatened in 1999.

Schoenoplectus hallii is a relatively uncommon emergent species from the central part of the United States in Georgia, Illinois, Indiana, Kansas, Kentucky, Massachusetts, Michigan, Missouri, Nebraska, Oklahoma, and Wisconsin. From six of these states it is known from a single population (Smith 2002). Many populations of this species probably represent accidental introductions as water birds are capable of transporting viable achenes long distances. Hall's bulrush is known from 23 populations, mostly from the Illinois River sand deposits of Cass and Mason counties (IDNR Natural Heritage Database 2005). During extremely wet years, this species becomes a common component of temporary sand ponds. During dry years, the achenes remain in the seed bank and are viable for more than 20 years (McClain et al. 1997). One population is known from protected land at Sand Prairie-Scrub Oak Nature Preserve in Mason County.

Illinois Collections: [Alexander Co., Horseshoe Lake Conservation Area, 5 Jul 1993 , M.A. Basinger 6042 (ILL); Cass Co., sand E of Beardstown, 13 Aug 1957, R.T. Rexroat 4142 (ISM); Kankakee Co., cultivated field, 26 Oct 1993, L.R. Phillippe 23379 (ILLS); Mason Co., W of Saidora, 22 Sep 1957, R.T. Rexroat 4367 (ILL, ISM)]. A Menard County record (Patterson 1876) could not be confirmed by herbaria searches.

Illinois Literature: Robertson et al. (1994), Basinger et al. (1997), McKenzie (1998), Mohlenbrock (2001), Baskin et al. (2003).

Scirpus microcarpus Presl. (small-fruited bulrush)

Specimens: Lake (F, MOR).

Status: Listed as Endangered in 1981, delisted in 1989, listed as Endangered in 2004.

Scirpus microcarpus is a relatively common species of marshes, moist meadows, and ditches throughout boreal Canada and south through most of the United States. All Illinois specimens are from the Lake Michigan Dunes Section of the Northeastern Morainal Natural Division in Lake County. In 1989, this species was considered extirpated from Illinois and delisted. Recently, a small colony of the smallfruited bulrush was found in Lake County and the species was again listed as state endangered in 2004 [two-track road, Illinois Beach State Park, 8 Jun 1999, G. Wilhelm 22774 (MOR)]. Dr. A.A. Reznicek, a recognized authority of this genus, has verified the identification of the specimens. Many disjunct, outlying populations in species such as the small-fruited bulrush, probably represent accidental introductions. 
This species should probably be considered adventive in Illinois and be removed from the endangered list.

Illinois Collections: [Lake Co., sewer ditch, Camp Logan, 29 Jun 1908, F.C. Gates 2770 (F)]. Small-fruited bulrush has only been collected four times in the state.

Illinois Literature: Gates (1912), Jones and Fuller (1955), Swink and Wilhelm (1994), Mohlenbrock (2001), Whittemore and Schuyler (2002), Nyboer and Ebinger (2004).

\section{IRIDACEAE}

Sisyrinchium atlanticum Bickn. (eastern blueeyed grass)

Specimens: Iroquois (EIU, ILL, ILLS, ISM, MOR), Kankakee (F, ILLS).

Status: Listed as Endangered in 1980, listed as Threatened in 2004.

Eastern blue-eyed grass is found throughout the eastern United States from Maine south to Florida, westward to Texas and north to eastern Illinois. Its northwestern range limit is in the Kankakee Sand Area Section of the Grand Prairie Natural Division in Iroquois and Kankakee counties, Illinois. The IDNR Natural Heritage Database (2005) reported eastern blue-eyed grass from 12 locations in the Kankakee sand deposits. Most records were from fallow fields and disturbed areas in sand prairies and savannas, but some were from dry-mesic savannas and mesic sand prairies. In Iroquois County, most of the populations were from Iroquois County Conservation Area and Hooper Branch Savanna Nature Preserve; in Kankakee County most collections were from Leesville Savanna Natural Area and Sweet Fern Savanna Land and Water Reserve.

Illinois Collections: [Kankakee Co., moist prairie, 9 miles E of Saint Anne, 27 Jul 1940, R.A. Schneider s.n. (F); Iroquois Co., Conservation Area, 27 May 1979, M. Hedborn \& E. Hedborn 1041 (MOR)]. The Du Page, Macoupin, and Montgomery county records reported by Herkert and Ebinger (2002) and the Macoupin, Pope, and Union county records reported by Mohlenbrock (2002), we believe, are based on misidentifications.

Illinois Literature: Gleason and Cronquist
(1991), Swink and Wilhelm (1994), Cholewa and Henderson (2002), Phillippe et al. (2002a, 2002b, 2003a).

\section{JUNCACEAE}

Juncus alpinoarticulatus Chaix (Richardson's rush, alpine rush)

Specimens: Cook (F, ILL, MOR), Du Page (MOR), Lake (EIU, F, ILL, ILLS, ISM, MO, MOR), McHenry (ILL).

Status: Listed as Endangered in 1980.

Synonyms: Juncus alpinus Vill.

Juncus alpinoarticulatus is a circumboreal species that is relatively common in the Great Lakes region and north through most of Canada, with scattered populations in the central plains and Rocky Mountains. Richardson's rush reaches its southern range limit in northeastern Illinois, occurring in fens, wet sand prairies, swales, and marshes of the Northeastern Morainal Natural Division in Cook, Du Page, Lake, and McHenry counties. In Cook County, this species was observed as a shoreline species at Wolf Lake Natural Area, at East Branch Forest Preserve, and recently at Montrose Beach Dunes (Masi - pers. comm.). In Lake County, populations were recently observed at Fisk Lake and Marl Flat Forest Preserve, Waukegan Beach, and Illinois Beach Nature Preserve (IDNR Natural Heritage Database 2005, 2009). One Du Page County specimen [East Branch Forest Preserve, 10 Aug 1979, W. Lampa s.n. (MOR)], and one McHenry County specimen [G. Vasey s.n. (ILL)] were found.

Illinois Collections: [Cook Co., South Chicago, 26 June 1875, E.J. Hill s.n. (F); Lake Co., wet borders of Bangs Lake, 5 Sep 1898, E.J. Hill 211 (ILL)]. A Kane County record reported by Herkert and Ebinger (2002) and an Ogle County record reported by Mohlenbrock (2002) have not been confirmed by herbaria searches.

Illinois Literature: Hill (1899b), Gates (1912), DeFilipps (1964, 1966), Mohlenbrock (1970a), Swink and Wilhelm (1994), Brooks and Clemants (2000).

\section{JUNCAGINACEAE}

Triglochin maritima L. (common bog arrowgrass) 
Specimens: Cook (F, ILL, SIU), Kane (MOR, SIU), Lake (EIU, F, ILL, ILLS, ISM, MOR, SIU), McHenry (F, ILL, ISM, KNOX, MOR), Tazewell (ILL), Will (ILLS, MOR).

Status: Listed as Endangered in 1980, changed to Threatened in 1999.

The geographic range of common bog arrowgrass extends throughout western North America and east through the Great Lakes into the northeastern United States and adjacent Canada (Haynes and Hellquist 2000). This species has a very restricted range in Illinois, nearly all specimens found are from marl flats of fens and swales in the Northeastern Morainal Natural Division in Cook, Kane, Lake, McHenry, and Will counties. Populations of common bog arrowgrass were observed at Nelson Lake Marsh Nature Preserve in Kane County in 1997. The Lake County populations were from Chain-O'-Lakes State Park, Fourth Lake Fen Nature Preserve, and Illinois Beach Nature Preserve where the species was relatively common in the 1990s, and reported as recently as 2009. McHenry County populations were found at the Julia M. and Royce L. Parker Nature Preserve, Lake-In-The-Hills Fen Nature Preserve, Sterne's Fen Nature Preserve, Kishwaukee Fen Nature Preserve, and Kettle Moraine Nature Preserve where the common bog arrowgrass was observed between 1988 and 1999 (IDNR Natural Heritage Database 2005, 2009). The collection from Tazewell County [1869, J.T. Stewart s.n. (ILL)], may not be correct, the specimen lacking critical collecting information. Illinois Collections: [Cook Co., 30 Jun 1859, F. Scammon s.n. (F); Lake Co., sand swamp, beach, 16 Jun 1907, F.C. Gates 1667 (ILL)]. A Peoria County record reported by Mohlenbrock (2002) could not be confirmed by herbaria searches.

Illinois Literature: Vasey (1861a, 1861b, 1870), Beal (1870), Gates (1912), Moran (1981), Bowles (1991a), Gleason and Cronquist (1991), Swink and Wilhelm (1994).

\section{ORCHIDACEAE}

Platanthera ciliaris (L.) Lindl. (orange fringed orchid, yellow fringed orchid)

Specimens: Cook (F, ILL, ILLS, ISM, MOR), Kankakee (ILLS).
Status: Listed as Endangered in 1980.

Orange fringed orchid is a species of moist sandy and peaty meadows, marshes, mesic sand prairies, and pine savannas in the eastern United States, from Florida to Massachusetts, west to east Texas and Illinois. Orange fringed orchid is rare in Illinois, with only two populations reported by the IDNR Natural Heritage Database $(2005,2009)$. All early collections are from the Northeastern Morainal Natural Division in Cook County. A population at Thornton-Lansing Road Nature Preserve in the Lake Michigan sands [Cook Co., wet mesic sand prairie, Thornton Forest Preserve, 26 Jul 1973, P. Shildneck C-5259 (ISM)], is probably still present (IDNR Natural Heritage Database $2005,2009)$. The orange fringed orchid was most recently collected in the Kankakee Sand Area Section of the Grand Prairie Natural Division [Kankakee Co., sand savanna, Leesville Savanna Natural Area, 22 Jul 2004, E. Smith, S. Becker, G. Hubert s.n. (ILLS)], where 83 flowering plants were found.

Illinois Collections: [Cook Co., wet places, Calumette, 15 Aug 1864, E.J. Hill s.n. (ILL)]. A Union County record, based on Patterson (1876), could not be confirmed by herbaria searches (Sheviak 1974).

Illinois Literature: Irwin and Reeder (1965), Winterringer (1967), Mohlenbrock (1970b), Luer (1975), Case, Jr. (1987), Swink and Wilhelm (1994).

Platanthera flava (L.) Lindl. var. herbiola (R. Br.) Luer (tubercled orchid)

Specimens: Carroll (ILLS), Cass (ISM, KNOX), Cook (F, ILL, ISU), Iroquois (ILLS), Kankakee (F, ILL, ISM, MOR), Lake (F, ILL, ILLS, ISM, MOR, SIU), Lee (ILLS, ISM), Mason (ILLS, ISM, MWI), Peoria (ILL), Tazewell (ILL), Wabash (ILL), Will (ILLS, MOR).

Stratus: Listed as Threatened in 1980, changed to Endangered in 1994, changed to Threatened in 2004.

The tubercled orchid is known from northeastern United States and adjacent Canada. In Illinois, populations are known from at least 20 sites (IDNR Natural Heritage Database 2005). In the Lake Michigan sand deposits, this species was recorded from Sand Ridge Nature 
Preserve and Thornton-Lansing Road Nature Preserve in Cook County and from MacArthur Woods Nature Preserve, Illinois Beach Nature Preserve, Spring Bluff Nature Preserve, Edward L. Ryerson Nature Preserve, and North Dunes Nature Preserve in Lake County. This orchid is common in the Kankakee sand deposits at the Iroquois County Conservation Area, four nature preserves in Will County where we have seen thousands of individuals, from the Illinois River sand deposits in Cass, Mason, Peoria, and Tazewell counties, and Lee County in the Green River Lowlands. The Carroll County record is recent [Upper Mississippi River National Wild Life \& Fish Refuge, 13 Jun 2007, R.L. Phillippe, C.J. Carroll, G. Cunningham \& J.E. Ebinger 39672 (ILLS)].

Illinois Collections: [Cass co., Beardstown, 10 Jun 1846, S.B. Mead s.n. (KNOX); Cook Co., Chicago, 17 Jun 1959, F. Scammon s.n. (F)]. The Ogle, St. Clair, Washington, and Whiteside county records reported by Herkert and Ebinger (2002) have not been confirmed by herbaria searches.

Illinois Literature: Winterringer (1967), Mohlenbrock (1970b), Sheviak (1974), Case, Jr. (1987), Swink and Wilhelm (1994), Lynn (2001), Phillippe et al. (2002b, 2003b).

Platanthera psycodes (L.) Lindl. (purple fringed orchid)

Specimens: Cook (CHIC, ILL, ILLS, ISM), Lake (ILL), Winnebago (ISM, NLI).

Status: Listed as Endangered in 1980.

Purple fringed orchid is known from boreal eastern Canada, the adjacent United States, and south in the Appalachians to North Carolina. It has a very restricted range in Illinois, and is known only from the Northeastern Morainal Natural Division in Cook, Lake, and Winnebago counties where it has been reported from low sand prairies, moist open woods, rich moist woods, wet ground, and most recently a sedge marsh. The purple fringed orchid was most recently collected in Illinois in 1999 from the edge of a marsh and flatwoods in Cook County (CHIC). In Lake County, the purple fringed orchid has been reported from MacArthur Woods Nature Preserve, Edward L. Ryerson Nature
Preserve, and Illinois Beach Nature Preserve where populations were observed between 1993 and 2003 (IDNR Natural Heritage Database 2005).

Illinois Collections: [Cook Co., Glencoe, 5 Aug 1873, P. Blatchford 2523 (ISM); Lake Co., beach region, $\mathrm{N}$ of Waukegan, $10 \mathrm{Jul}$ 1908, F.C. Gates 2840 (ILL); Winnebago Co., Sugar River bottom, 4 miles NW of Shirland, 19 Jul 1946, E.W. Fell \& G.B. Fell 46-557 (ISM, NLI)]. A LaSalle County record reported by Herkert and Ebinger (2002) and by Mohlenbrock (2002) could not be confirmed by herbaria searches. Illinois Literature: Ames (1910), Gates (1912), Fell (1955, 1957), Winterringer (1967), Mohlenbrock (1970b), Sheviak (1974), Luer (1975), Case, Jr. (1987), Jones (1994), Swink and Wilhelm (1994),

\section{POACEAE}

Ammophila breviligulata Fern. (marram grass, beach grass)

Specimens: Cook (F, ILL, ILLS, ISM, ISU, MOR, SIU), Lake (F, EIU, ILLS, ISM, MOR).

Status: Listed as endangered in 1980.

Beach grass is common on sandy shores throughout the Great Lakes, Lake St. John, Lake Champlain, and along the Atlantic coast from Newfoundland to South Carolina (Barkworth 2007). Beach grass is a characteristic species along Lake Michigan where it is the dominant and often the first perennial plant present for any extensive dune formation on the upper beach or foredune. All Illinois specimens are from the Northeastern Morainal Natural Division. Populations of this species are relatively common from Illinois Beach Nature Preserve and North Dunes Nature Preserve. Nearly all populations, however, are threatened by habitat destruction due to human interference, off-road vehicles, and by accelerated shoreline erosion. This species has commonly been planted to stabilize dunes.

Illinois Collections: [Cook Co., Chicago, Sep 1860, F. Scammon s.n. (F); Lake Co., beach, 11 Sep 1909, F.C. Gates 3281 (F)]. Beach grass is still common on private land, parks, and preserves with more than 10 sightings reported in the IDNR Natural Heritage Database (2005, 2009). 
Illinois Literature: Beal (1870), Vasey (1870), Cowles (1899), Gates (1912), Fuller (1934), Guire and Voss (1963), Mohlenbrock (1972), Greenberg and Milde (1994), Swink and Wilhelm (1994), Delisle-Oldham et al. (2008).

Bouteloua gracilis (HBK) Lag. (blue grama, eyelash grass)

Specimens: Champaign (ILL), Cook (MOR), Jo Daviess (ILL, ILLS), Lake (ISM), Morgan (ISM, SIU, MWI), Williamson (ILL).

Status: Listed as Endangered in 1999.

The geographic range of blue grama extends from south central Canada south through the Great Plains to central Mexico. Rare east of the Mississippi River, blue grama has a sporadic occurrence as far east as Ohio (Wipff 2003). Mohlenbrock (2002) reported this taxon from Carroll, Champaign, Henry, Jo Daviess, Lake, and Morgan counties. Probably the only indigenous population in Illinois, however, is the one reported for Jo Daviess County. This population may represent a relict population from the hypsothermal after Wisconsian glaciation when the climate was drier and warmer [Jo Daviess Co., Lost Mound Unit, Upper Mississippi River National Wildlife and Fish Refuge, degraded sand prairie, 23 Oct 1996, L.R. Phillippe \& K.R. Robertson 28594 (ILLS)].

Illinois Collections: [Jo Daviess Co., sand flats, 18 Jul 1908, H.S. Pepoon s.n. (ILL)]. Collections of blue grama from other counties in Illinois are adventive or planted, being reported from old fields, strip mined land, and railroad ballasts. The report of this species from Carroll and Henry counties by Mohlenbrock (2002) could not be confirmed by herbaria searches. Illinois Literature: Gleason (1910), Riegel (1941), Fuller (1945), Hitchcock and Chase (1950), Dolbeare (1973), Bowles and Jones (1995), Robertson et al. (1997). 


\section{LITERATURE CITED}

Adams, R.P. 1993. Juniper in Flora of North America North of Mexico. 2:412-420.

Ames, O. 1910. The genus Habenaria in North America. Orchidaceae. fascicle IV, The Merrymount Press, Boston, New York. xiv + 288 pp.

Anderson, R.C., and D. Ugent. 1980. Floristic provinces of Illinois. Chicago Academy of Sciences Natural History Miscellanea 210:1-6.

Atwell, C.B. 1932. Three dune associations compared. Torreya 32:109-115.

Babcock, H.H. 1872. The flora of Chicago and vicinity. The Lens 1:218-222.

Barkworth, M.E. 2007. Ammophila in Flora of North America North of Mexico. 24:776-778.

Basinger, M.A., J.S. Huston, R.J. Gates, and P.A. Robertson. 1997. Vascular flora of Horseshoe Lake Conservation Area, Alexander County, Illinois. Castanea 62:82-99.

Baskin, C.C., J.M. Baskin, E.W. Chester, and M. Smith. 2003. Ethylene as a possible cue for seed germination of Schoenoplectus hallii (Cyperaceae), a rare summer annual of occasionally flooded sites. American Journal of Botany 90:620-627.

Beal, W.J. 1870. A stroll along the beach of Lake Michigan. American Naturalist 4:356358.

Beattie, A.J., and D.C. Culver. 1977. Effects of the mound nests of the ant, Formica obscuripes, on the surrounding vegetation. American Midland Naturalist 97:390-399.

Bebb, M.S. 1859. List of plants occurring in the northern counties of the state of Illinois: In addition to the catalogue given by Dr. J.A. Lapham. Transactions of the Illinois State Agricultural Society 3:586-587.
Bierner, M.W., and B.L. Turner. 2006. Tetraneuris in Flora of North America North of Mexico 21:447-453.

Bornstein, A.J. 1997. Myricaceae in Flora of North America North of Mexico 3:429-435.

Bowles, M.L. 1991a. Some aspects of the status and ecology of seven rare wetland plant species in the Chicago Region of northeastern Illinois. Erigenia 11:52-66.

Bowles, M.L. 1991b. Illinois reproduction plan for the federal threatened Pitcher's thistle (Cirsium pitcheri). The Morton Arboretum, Lisle, Illinois.

Bowles, M., and M. Jones. 1991. Report on the status of Illinois endangered, threatened, and rare vascular plant species at the Savanna Army Depot, Carroll County and Jo Daviess County, Illinois. The Morton Arboretum, Lisle, Illinois.

Bowles, M., and M. Jones. 1995. Management and research needs for endangered and threatened plants, sand prairie vegetation, and habitat-restricted animal species at the Savanna Army Depot, Carroll County and Jo Daviess County, Illinois. Report to the Savanna Army Depot, Morton Arboretum, Lisle, Illinois. 21 pp. +4 figures +1 appendix.

Bowles, M., R. Flakne, K. McEachern, and N. Pavlovic. 1993. Recovery planning and reintroduction of the federally threatened Pitcher's Thistle (Cirsium pitcheri) in Illinois. Natural Areas Journal 13:164-176.

Bowles, M.L., J.B. Taft, E.F. Ulaszek, M.K. Solecki, D.M. Ketzner, L.R. Phillippe, A. Dennis, P.J. Burton, and K.R. Robertson. 1991. Rarely seen endangered plant rediscoveries and species new to Illinois. Erigenia 11:27-51.

Brendel, F. 1859. Trees and shrubs in Illinois. Transactions of the Illinois State Agricultural Society 3:588-604. 
Brooks, R.E., and S.E. Clemants. 2000. Juncus in Flora of North American North of Mexico 22:211-255.

Carroll, C.J., and M.A. Feist. 2004. Rediscovery of Baptisia tinctoria (L.) Brown (Fabaceae) in Illinois. Castanea 69:234-236.

Case, Jr., F.W. 1987. Orchids of western Great Lakes region. Revised Edition. Cranbook Institute of Science Bulletin 48. Edwards Brothers, Inc., Ann Arbor, Michigan. xxi + 251 pp.

Cholewa, A.F. ,and D.M. Henderson. 2002. Sisyrinchium in Flora of North America North of Mexico. 26:351-371.

Clute, W.N. 1904. Actinella acaulis. American Botanist 6:96.

Clute, W.N. 1931. Swamp and dune. A study in plant distribution. Willard N. Clute andCompany, Indianapolis, Indiana. $92 \mathrm{pp}$.

Clute, W.N. 1946. One of our rarest plants. American Botanist 52:33-34.

Coates, D.T., S.E. Jenkins, J.E. Ebinger, and W.E. McClain. 1992. Woody vegetation survey of Barkhausen Woods, a closed canopy sand forest in Mason County, Illinois. Erigenia 12:1-6.

Cowles, H.C. 1899. The ecological relations of the vegetation on the sand dunes of Lake Michigan. Botanical Gazette 27:95-117, 167-202, 281-308, 361-391.

Crins, W.J., and P.W. Ball. 1983. The taxonomy of Carex pennsylvanica complex (Cyperaceae) in North America. Canadian Journal of Botany 61:1692-1717.

Crins, W.J., and J.H. Retting. 2002. Carex sect. Montanae in Flora of North America North of Mexico 23:532-545.
Cusick, A.W. 1991. Hymenoxys herbacea (Asteraceae): an endemic species of the Great Lakes Region. Rhodora 93:238-241.

DeFilipps, R.A. 1964. A taxonomic study of Juncus in Illinois. American Midland Naturalist 71:296-319.

DeFilipps, R.A. 1966. Distribution of Juncus in Illinois. Phytologia 13:44-64.

Delisle-Oldham, M.B., M.J. Oldham, and P.M. Catling. 2008. Taxonomic recognition of Ammophilia champlainensis and morphological variation in northeastern North America Ammophila (Poaceae). Rhodora 110:129-156.

DeMauro, M.M. 1990. Recovery plan for the lakeside daisy (Hymenoxys acaulis var. glabra). Report prepared for Region U.S. Fish and Wildlife Service, Twin Cities, Minnesota. 91 pp.

DeMauro, M.M. 1993. Relationship of breeding systems to rarity in the lakeside daisy (Hymenoxys acaulis var. glabra). Conservation Boiology 7:542-550.

DeMauro, M.M. 1994. Development and implementation of a recovery program for the federal threatened lakeside daisy (Hymenocaulis acaulis var. glabra). Pages 298-321 in Restoration of endangered species: conceptual issues, planning, and implementation (M.L. Bowles and C.J. Whelan, eds.). Cambridge University Press, Cambridge, Massachusetts.

Dolbeare, B.L. 1973. Plant collections of Rollo T. Rexroat. Transactions of the Illinois State Academy of Science 66:81-93.

Duerr, J.J. 1967. A study of succession on an acid peat bog in Kane County. M.S. thesis. Northern Illinois University, DeKalb. 59 pp. 
Ebinger, J.E., L.R. Phillippe, D.T. Busemeyer, P.B. Marcum, M.A. Feist and W.E. McClain. 2007. Vegetation of isolated sand deposits along the Illinois River. Illinois Natural History Survey Section for Biodiversity Technical Report 2007 (20). Prepared for the Illinois Department of Natural Resources, Office of Resource Conservation, Springflield.

Ebinger, J.E., L.R. Phillippe, R.W. Nyboer, W.E. McClain, D.T. Busemeyer, K.P. Robertson, and G.A. Levin. 2006. Vegetation and flora of the sand deposits of the Mississippi River valley in northern Illinois. Illinois Natural History Survey Bulletin 37(6):191-238.

Ebinger, J.E., L.R. Phillippe, W.C. Handel, C.J. Cunningham, W.E. McClain, R.W. Nyboer, and T. Bittner. 2008. Plant Communities of the Green River Lowlands in Northwestern Illinois. Illinois Natural History Survey Technical Report 2008 (21), Prepared for the Illinois Department of Natural Resources, Special Wildlife Funds Grant for Illinois Wildlife Preservation Fund.

Ebinger, J.E., L.R. Phillippe, W.C. Handel, C.J. Cunningham, W.E. McClain, R.W. Nyboer, and T. Bittner, 2009. Vascular plant communities of the Green River Lowlands in northwestern Illinois. Illinois Natural History Survey Bulletin 39(2):39-78.

Ebinger, J.E., L.R. Phillippe, M.J.C. Murphy, G.C. Tucker and P. Marcum. 2010. Vascular plant species extirpated or not vouchered as occurring in Illinois. Erigenia 23:3-23.

Evers, R.A. 1963. Some unusual natural areas in Illinois and a few of their plants. Illinois Natural History Survey Biological Notes 50. $32 \mathrm{pp}$.

Evers, R.A., and L.M. Page. 1977. Some unusual natural areas in Illinois. Illinois Natural History Survey Biological Notes 100.
Fant, J.B., R.M. Holstrum, E. Sirkin, J.R. Etterson, and S. Masi. 2008. Genetic structure of threatened native populations and propagules used for restoration, in a clonal species, Ammophila breviligulata Fern. (American beachgrass). Restoration Ecology 16:594-603.

Fassett, N.C. 1961. The leguminous plants of Wisconsin. University of Wisconsin Press, Madison.

Fehrenbacher, J.B., J.D. Alexander, I.J. Jansen, R.G. Darmody, R.A. Pope, M.A. Flock, E.E. Voss, J.W. Scott, W.F. Andrews, and L.J. Bushue. 1984. Soils of Illinois. University of Illinois at Urbana-Champaign College of Agriculture and Agricultural Experiment Station in Cooperation with the Soil Conservation Service, U.S. Department of Agriculture, Bulletin 778. 85 pp.+ map.

Feist, M.A, M. Moore, L.R. Phillippe, J.E. Ebinger, and W.E. McClain. 2008. Sand prairie communities of Matanzas Prairie Nature Preserve, Mason County, Illinois. Castanea 73:177-187.

Fell, E.W. 1955. Flora of Winnebago County, Illinois: an annotated list of the vascular plants. Nature Conservancy, Washington, D.C. 207 pp.

Fell, E.W. 1957. Plants of a northern Illinois sand deposit. American Midland Naturalist 58:441-451.

Fell, E.W. 1959. The genus Carex in Rock River Valley in Northern Illinois. Natural Land Institute, Rockford, Illinois. 52 pp.

Fell, E.W., and G.B. Fell. 1956. The gravel-hill prairies of Rock River Valley in Illinois. Transactions of the Illinois State Academy of Science 49:47-62.

Fernald, E.I. 1940. Preliminary checklist of herbaceous plants of Winnebago County, Illinois. Rockford College, Rockford. 45 pp. 
Fernald, M.L., and B.G. Schubert. 1949. Contributions from the Gray Herbarium of Harvard University 169. Part 1: Some identities in Breweria. Rhodora 51:35-43 + 9 figs.

Frankie, W.T., M.M. Killey, and R.J. Russell. 1996. Guide to the geology of the Hoopeston area, Vermilion and Iroquois counties, Illinois. Illinois State Geological Survey, Field Trip Guidebook. 1996B, 54 pp.

Fuller, G.D. 1914. Evaporation and soil moisture in relation to the succession of plant associations. Botanical Gazette 58:193-234.

Fuller, G.D. 1925. The vegetation of the Chicago Region. University of Chicago Press, Chicago. 27 pp.

Fuller, G.D. 1934. The plant communities of the dunes. Scientific Monthly 38:444-451.

Fuller, G.D. 1945. A checklist of the vascular plants of Jo Daviess County, Illinois. Transactions of the Illinois State Academy of Science 38:51-63.

Fuller, G.D., E.W. Fell, and G.B. Fell. 1949. Checklist of the vascular plants of Winnebago County, Illinois. Transactions of the Illinois State Academy of Science 42:68-79.

Gambill, W.G., Jr. 1953. The Leguminosae of Illinois. Illinois Biological Monographs 22(4). University of Illinois Press, UrbanaChampaign. 117 pp.

Gates, F.C. 1910. Relic dunes, a life history. Transactions of the Illinois State Academy of Science 3:110-116.

Gates, F.C. 1912. The vegetation of the beach area in northeastern Illinois and southeastern Wisconsin. Illinois State Laboratory of Natural History Bulletin 9:255-372.

Gleason, H.A. 1909. The vegetational history of a river dune. Transactions of the Illinois State Academy of Science 2:19-26.
Gleason, H.A. 1910. The vegetation of the inland sand deposits of Illinois. Illinois State Laboratory of Natural History Bulletin 9:23174.

Gleason, H.A. 1922. The vegetational history of the middlewest. Annals of the Association of American Geographers 12:39-85.

Gleason, H.A., and A. Cronquist. 1991. Manual of vascular plants of northeastern United States and adjacent Canada. The New York Botanical Garden, Bronx. lxxv + 910 pp.

Gleason, H.A., and F.C. Gates. 1912. A comparison of the rates of evaporation in certain associations in central Illinois. Botanical Gazette 53:478-491.

Gray, A.G. 1867. Manual of the botany of the Northern United States, $5^{\text {th }}$ edition. American Book Company, Chicago.

Great Plains Flora Association. 1986. Flora of the Great Plains. University Press of Kansas, Lawrence. vii + 1402 pp.

Greenberg, J., and M.R. Milde. 1994. The occurrence of four rare plants in Cook County. Transactions of the Illinois Academy of Science 87:113-115.

Guire, K.E., and E.G. Voss. 1963. Distributions of distinctive shoreline plants in the Great Lakes Region. Michigan Botanist 2:99-114.

Handel, W.C., L.R. Phillippe, and J.E. Ebinger. 2003. Floristic assessment of sand prairies and sedge meadows, Lee County, Illinois. The Prairie Naturalist 35:33-46.

Hart, C.A., and H.A. Gleason. 1907. On the biology of the sand areas of Illinois. Bulletin of the Illinois State Laboratory of Natural History 7:137-272.

Haynes, R.R., and C.B. Hellquist. 2000. Juncaginaceae in Flora of North America North of Mexico 22:43-46. 
Herkert, J.R., and J.E. Ebinger. 2002. (eds.) Endangered and threatened species of Illinois: status and distribution, Volume 1 - Plants. Illinois Endangered Species Protection Board, Springfield. $161 \mathrm{pp}$.

Higley, W.K., and C.S. Raddin. 1891. The flora of Cook County, Illinois, and a part of Lake County, Indiana. Chicago Academy of Sciences Bulletin 2:xxiii + 168 pp.

Hill, E.J. 1890. Plant notes [Hypericum kalmianum and Lobelia kalmii]. Garden and Forest 127:370.

Hill, E.J. 1899a. Kalm's St. John's-Wort (Hypericum kalmianum) west of Michigan. The Plant World 2:73--75.

Hill, E.J. 1899b. Notes on the plants of the Chicago district. Bulletin of the Torrey Botanical Club 29:303-311.

Hill, E.J. 1910. The pasture thistle, east and west. Rhodora 12:211-214.

Hitchcock, A.S., and A. Chase. 1950. Manual of the grasses of the United States. ${ }^{\text {nd }}$. Edition. United States Government Printing Office, Washington. $1051 \mathrm{pp}$.

Illinois Endangered Species Protection Board. 2005. Checklist of endangered and threatened animals and plants of Illinois. Illinois Endangered Species Protection Board, Springfield. 16 pp.

IDNR Natural Heritage Database 2005. (Illinois Department of Natural Resources)

IDNR Natural Heritage Database 2009. Irwin, F.G., and P. Reeder. 1965. Wild orchids of Illinois. Outdoor Illinois 4:4-14.

Isely, D. 1998. Native and naturalized Leguminosae (Fabaceae) of the United States (exclusive of Alaska and Hawaii). Monte L. Bean Life Science Museum, Brigham Young University, Provo Utah. xi+1007 pp.
Jenkins, S.E., J.E. Ebinger, and W.E. McClain. 1991. Woody vegetation survey of Bishop's Woods, a sand forest in Mason County, Illinois. Transactions of the Illinois State Academy of Science 84:20-27.

Johnson, K.C., and J.E. Ebinger. 1992. Effects of prescribed burns on the woody vegetation of a dry sand savanna, Hooper Branch Nature Preserve, Iroquois County, Illinois. Transactions of the Illinois State Academy of Science. 85:105-111.

Johnson, K.C., and J.E. Ebinger. 1995. Effects of different fire regimes on the ground layer vegetation of a dry sand savanna, Hooper Branch Nature Preserve, Iroquois County, Illinois. Erigenia 14:37-40.

Jones, G.N. 1952. Type localities of vascular plants first described from Illinois. American Midland Naturalist 47:487-507.

Jones, G.N., and G.D. Fuller. 1955. Vascular plants of Illinois. The University of Illinois Press, Urbana. 593 pp.

Jones, M.D. 1994. The flora and vegetational history of Winnebago County, Illinois. Winnebago County Forest Preserve District, Rockford, Illinois. $\mathrm{x}+225 \mathrm{pp}$.

Keddy, P.A. 1982. Population ecology on an environmental gradient: Cakile edentula, on a sand dune. Oecologia 52:348-355.

Keil, D.J. 2006. Cirsium in Flora of North America North of Mexico 19:95-164.

Kieninger, T. 2009a. e-mail dated 1 April 2009. (Illinois Department of Natural Resources Natural Heritage Database).

Kieninger, T. 2009b. e-mail dated 15 October 2009. (Illinois Department of Natural Resources Natural Heritage Database). 
Killey, M.M. 1998a. Glacial and surfical geology. Pages 15-19, in Lower Rock River Area Assessment. Volume 1. Geology (no editor), Critical Trends Assessment Program, Illinois Department of Natural Resources and the State Geological Survey Division, Champaign.

Killey, M.M. 1998b. Illinois’ Ice Age legacy. Illinois State Geological Survey; Geoscience Education Series 14. 66 pp.

King, J.E. 1981. Late Quaternary vegetational history of Illinois. Ecological Monographs 51:43-62.

Kral, R. 1971. A treatment of Abildgaardia, Bulbostylis, and Fimbristylis (Cyperaceae) for North America. Sida 4:57-227.

Kral, R. 2002. Fimbristylis in Flora of North America North of Mexico. 23:121-131.

Larisey, M.M. 1940. A monograph of the genus Baptisia. Annals of the Missouri Botanical Garden 27:119-218 + 28 plates.

Lineback, J.A. 1979. Quaternary deposits of Illinois. Illinois State Geological Survey. Map.

Luer, C.A. 1975. The native orchids of the United States and Canada excluding Florida. W.S. Cowell Ltd, Ipswich, England. 361 pp.

Lynn, K.W. 2001. Additions to the orchid flora of Madison County, Illinois. Transactions of the Illinois State Academy of Science 94:207-212.

Maier, C.T. 1976. An annotated list of the vascular plants of Sand Ridge State Forest, Mason County, Illinois. Transactions of the Illinois State Academy of Science 69:153-175.

Mastrogiuseppe, J., P.E. Rothrock, A.C. Dibble, and A.A. Reznicek. 2002. Carex sect. Ovales in Flora of North America North of Mexico. 23:332-378.
McClain, W.E., and J.E. Ebinger. 2002. Status of Hymenopappus scabiosaeus L'Hr. (Asteraceae) in Illinois. Transactions of the Illinois State Academy of Science 95:145-151.

McClain, W.E., and J.E. Ebinger. 2003. The genus Astragalus (Fabaceae) in Illinois. Transactions of the Illinois State Academy of Science 97:11-18.

McClain, W.E., R.D. McClain, and J.E. Ebiger. 1997. Flora of temporary sand ponds in Cass and Mason Counties, Illinois. Castanea 62:65-73.

McClain, W.E., L.R. Phillippe, and J.E. Ebinger. 2003. Floristic assessment of Foley Sand Prairie Nature Preserve, Lee County, Illinois. Transactions of the Illinois State Academy of Science 96:255-263.

McClain, W.E., L.R. Phillippe, and J.E. Ebinger. 2004a. Vascular flora of Manito Prairie Nature Preserve, Tazewell County, Illinois. Transactions of the Illinois State Academy of Science 97:83-94.

McClain, W.E., L.R. Phillippe, and J.E. Ebinger. 2004b. Floristic assessment of the Henry Allan Gleason Nature Preserve, Mason County, Illinois. Castanea 70:146-154.

McClain, W.E., L.R. Phillippe, and J.E. Ebinger. 2005. Floristic assessment of the Henry Allan Gleason Nature Preserve, Mason County, Illinois. Castanea 70:146-154.

McClain, W.E., L.R. Phillippe, and J.E. Ebinger. 2008. Seep community at White Oak Creek Woods Natural Area, Mason County, Illinois. Transactions of the Illinois State Academy of Science 101:147-156.

McClain, W.E., S.D. Turner, and J.E. Ebinger. 2002. Vegetation of forest communities at the Sand Prairie-Scrub Oak Nature Preserve, Mason County, Illinois. Transactions of the Illinois State Academy of Science 95:37-46. 
McDonald, F.E. 1900. A sand dune flora of central Illinois. Plant World 3:101-103.

McDowell, B., J. Newman, and J. Ebinger. 1983. Survey of the woody vegetation of the Kankakee Sand Area Section of Indiana and Illinois. Proceedings of the Indiana Academy of Science 93:187-193.

McEarchen, A.K. 1992. Disturbance dynamics of Pitcher's thistle (Cirsium pitcheri)recovery in Great Lakes sand dune landscapes. Ph.D. dissertation. University of Wisconsin, Madison.

McFall, D., and M. Jones. 1972. Some interesting fern finds and records in northern Illinois. American Fern Journal 62:47-48.

McFall, D., and J. Karnes. 1995. (eds.) A directory of Illinois Nature Preserves, Volume 1 - Northeastern Illinois. Illinois Department of Natural Resources, Springfield. 195 pp.

McKenzie, P.M. 1998. Hall's bulrush (Schoenoplectus hallii) status assessment. Final report submitted to U.S. Fish and Wildlife Service. Minneapolis, Minnesota.

Mead, S.B. 1846. Catalogue of plants growing spontaneously in the state of Illinois, the principal part near Augusta, Hancock County. Prairie Farmer 6:35-36, 60, 93, 119-122.

Mohlenbrock, R.H. 1959. A new species of Cyperus from the Illinois sand prairies. Brittonia 11:255-256.

Mohlenbrock, R.H. 1969. The wild violets of Illinois. Outdoor Illinois (May) 8:20-33.

Mohlenbrock, R.H. 1970a. The Illustrated flora of Illinois, flowering plants: rush to rushes. Southern Illinois University Press, Carbondale. 272 pp.

Mohlenbrock, R.H. 1970b. The illustrated flora of Illinois: lilies to orchids. Southern Illinois University Press, Carbondale. xii + 288 pp.
Mohlenbrock, R.H. 1972. The illustrated flora of Illinois, grasses: Bromus to Paspalum. Southern Illinois University Press, Carbonale.

Mohlenbrock, R.H. 1978. The illustrated flora of Illinois, flowering plants: hollies to loasas. Southern Illinois University Press, Carbondale. xii +315 pp.

Mohlenbrock, R.H. 1980. The illustrated flora of Illinois, flowering plants: willows to mustards. Southern Illinois University Press, Carbondale. $x i i+286$ pp.

Mohlenbrock, R.H. 1982a. Illinois Convolvulaceae in the Missouri Botanical Garden Herbarium. Annals of the Missouri Botanical Garden 69:393-401.

Mohlenbrock, R.H. 1982b. The illustrated flora of Illinois, flowering plants: basswoods to spurges. Southern Illinois University Press, Carbondale. $x i+234$ pp.

Mohlenbrock, R.H. 1999a. The illustrated flora of Illinois, ferns. Southern Illinois University Press, Carbondale. xiii +240 pp.

Mohlenbrock, R.H. 1999b. The illustrated flora of Illinois. Sedges: Carex. Southern Illinois University Press, Carbondale. 328 pp.

Mohlenbrock, R.H. 2001. The illustrated flora of Illinois. Sedges: Cyperus to Scleria. Southern Illinois University Press, Carbondale. 223 pp.

Mohlenbrock, R.H. 2002. Vascular flora of Illinois. Southern Illinois University Press, Carbondale. xiv +491 pp.

Mohlenbrock, R.H., and L.R. Stritch. 1985. The genus Penstemon (Scrophulariaceae) in Illinois. Erigenia 6:5-16.

Mohlenbrock, R.H., and P.M. Thomson, Jr. 1987. The illustrated flora of Illinois, flowering plants: smartweeds to hazelnuts. Southern Illinois University Press, Carbondale. $x i+228$ pp. 
Moran, R.C. 1978. Vascular flora of the ravines along Lake Michigan in Lake County, Illinois. Michigan Botanist 17:123-140.

Moran, R.C. 1981. Prairie fens in northeastern Illinois: floristic composition and disturbance. Pages 164-168 in R.L. Stuckey, and K.J. Reese, eds. Proceedings of the Sixth North American Prairie Conference. Ohio Biological Survey Notes 15, Columbus.

Moran-Palma, P., and A.A. Snow. 1997. The effect of interplant distance on mating success in federally threatened, self-incompatible Hymneoxys herbacea $=H$. acaulis var. glabra (Asteraceae). American Journal of Botany 84:233-238.

Munz, P.A. 1930.The North American species of Orobanche, Section Mycorrhiza. Bulletin of the Torrey Botanical Club 57:611-623.

Murphy, M.J., L.R. Phillippe, and J.E. Ebinger. 2009. Vascular flora of Bonnie's Prairie Nature Preserve, Iroquois County, Illinois. Transactions of the Illinois State Academy of Science 102:1-19.

Nyboer, R.W., and J.E. Ebinger. 2004. (eds.) Endangered and threatened species of Illinois: status and distribution. Volume 3: 2004 Changes to the Illinois list of endangered and threatened plant species. Illinois Endangered Species Protection Board. Springfield. 34 pp.

Patterson, H.N. 1874. A list of plants collected in the vicinity of Oquawka, Henderson County. Spectator Printers, Oquawka, Illinois. 18 pp.

Patterson, H.N. 1876. Catalogue of the phaenogamous and vascular cryptogamous plants of Illinois, native and introduced. Spectator Printers, Oquawka, Illinois. 54 pp.

Payson, E.B. 1921. A monograph of the genus Lesquerella. Annals of the Missouri Botanical Garden 8:103-236.
Pennell, F.W. 1935. The Scrophulariaceae of eastern temperate North America. Academy of Natural Sciences of Philadelphia, Monograph Number 1, xiv + 650 pp.

Pepoon, H.S. 1927. An annotated flora of the Chicago area. Bulletin of the Chicago Academy of Sciences 8:1-554.

Phillippe, L.R., D.T. Busemeyer, P.B. Marcum, M.A. Feist, C.J. Carroll, K.J. Hunter, G.R. Spyreas, and J.E. Ebinger. 2003a. Vascular flora of the Pembroke savannas, Kankakee County, Illinois. Illinois Natural History Survey, Center for Biodiversity Technical Report 2003(8) Prepared for the Illinois Department of Natural Resources, Wildlife Preservation Fund, Springfield. $120 \mathrm{pp}$.

Phillippe, L.R., D.T. Busemeyer, P.B. Marcum, M.A. Feist, and J.E. Ebinger. 2008. Prairie and savanna vegetation of Braidwood Dunes and Savanna Nature Preserve, Will County, Illinois. Castanea 73:1-15

Phillippe, L.R., J.E. Ebinger, R. Nyboer, D.T. Busemeyer, and K.J. Hunter. 2003b. Vegetation analysis of forest communities before and after cutting, and the evaluation of potential natural areas at the Green River State Wildlife Area, Lee County, Illinois. Illinois Natural History Survey, Center for Biodiversity Technical Report 2003 (30). Prepared for the Illinois Department of Natural Resources, Wildlife Preservation Fund, Springfield. 63 pp +2 appendices.

Phillippe, L.R. J. Ellis, D.T. Busemeyer, W.E. McClain, and J.E. Ebinger 2009. Vegetation survey of Tomlin Timber Nature Preserve, Mason County, Illinois. Erigenia 22:36-44. 
Phillippe, L.R. M.A. Feist, R.L. Larimore, D. Busemeyer, P. Marcum, C. Carroll, K.J. Hunter, and J.E. Ebinger. 2002a. Vascular flora of Iroquois County Conservation Area and Hooper Branch Nature Preserve, Iroquois County, Illinois. Illinois Natural History Survey, Center for Biodiversity Technical Report 2002(3) Prepared for the Illinois Department of Natural Resources, Wildlife Preservation Fund, Springfield. 36 pp.

Phillippe, L.R., M.A. Feist, R.L. Larimore, D. Busemeyer, P. Marcum, C. Carroll, K.J. Hunter, and J.E. Ebinger. 2002b. Vascular flora of Hooper Branch Savanna Nature Preserve, Iroquois County, Illinois. Illinois Natural History Survey Technical Report 2002 (3B). Prepared for the Illinois Department of Natural Resources, Division of Natural Heritage, Wildlife Preservation Fund, Springfield.

Phillippe, L.R., M.A.Feist, J.E. Ebinger, and W.E. McClain. 2004. Vascular flora of Long Branch Nature Preserve, Mason County, Illinois. Transactions of the Illinois State Academy of Science 97:197-208.

Phillippe, L.R., B. Molano-Flores, M.J.C. Murphy, and J.E. Ebinger. 2006. Development of a recovery strategy for endangered plant species through habitat recovery, preservation, and management. Center for Biodiversity. Illinois Natural History Survey Technical Report 2006(5) Prepared for the Illinois Endangered Species Protection Board, Springfield

Phillippe, L.R., W.C. Handel, S. Horn, and J.E. Ebinger. 1999. Vascular flora of Momence Wetlands, Kankakee County, Illinois. Illinois Natural History Survey Technical Report 1999 (26). Prepared for the Illinois Department of Natural Resources, Division of Natural Heritage, Wildlife Preservation Fund, Springfield.

Pinkava, D.J. 2003. Opuntia in Flora of North America North of Mexico 4:123-148.

Post, T.W., J.A. Bacone, and J.R. Aldrich. 1985. Gravel prairies of Indiana. Proceedings of the Indiana Academy 94:457-463.
Ribbens, E. and B.A. Anderson. 2008. Opuntia fragilis in Illinois. Cactus and Succulent Journal 80:119-122.

Riegel, A. 1941. Life history and habits of blue grama. Transactions of the Kansas Academy of Science 44:76-85 + 6 figs.

Robinson, A. 1995. Small and seasonal does not mean insignificant: why it's worth standing up for tiny and temporary wetlands. Journal of Soil and Water Conservation 50:586-590.

Robertson, K.R., L.R. Phillippe, and S.M. Gehlhausen. 1994. The current status of Scirpus hallii A. Gray, Hall's bulrush, in Illinois. Illinois Natural History Survey Center for Biodiversity. Technical Report 1994(1). 29 pp. + maps.

Robertson, K.R., L.R. Phillippe, G.A. Levin, and M.J. Moore. 1997. Delineation of natural communities, a checklist of vascular plants, and new locations for rare plants at the Savanna Army Depot, Carroll and Jo Daviess counties, Illinois. Illinois Natural History Survey, Center for Biodiversity, Technical Report 1997 (2). 90 pp. + maps.

Rollins, R.C. 1993. The Cruciferae of continental North America. Stanford University Press, Stanford, California. xvi + 976 pp.

Ross, H.H. 1963. The dunesland heritage of Illinois. Illinois Natural History Survey Circular 49, Champaign. 28 pp.

Russell, N.H. 1965. Violets (Viola) of central and eastern United States: an introductory survey. Sida 2:1-113.

Rydberg, P.A. 1932. Flora of the prairies and plains of central North America. New York Botanical Garden, New York. 969 pp.

Schwegman, J.E. 1973. Comprehensive plan for the Illinois nature preserves system. Part 2. The natural divisions of Illinois. Illinois Nature Preserves Commission, Rockford, Illinois. map +32 pp. 
Schwegman, J.E. 1984. Scirpus mucronatus and Valerianella chenopodifolia in Illinois. Transactions of the Illinois State Academy of Science 77:67-69.

Schwegman, J.E. 1990. Preliminary results of a program to monitor plant species for management purposes. Pages 113-116 in R.S. Mitchell, C.J. Sheviak, and D.J. Leopold, eds. Ecosystem management: rare species and significant habitats. New York State Museum Bulletin 471, Albany.

Schwegman, J.E. 1991. New records for Illinois vascular plants. Erigenia 11:9-12.

Scott, L., and B. Molano-Flores. 2007. Reproductive output and biology of Rudbeckia fulgida var. sullivantii (C.L. Boynt and Beadle) Cronq., (Sullivant's coneflower, Asteraceae) a USDA Regional Forester Sensitive Species. Journal of the Torrey Botanical Society 134:362-368.

Sheviak, C.J. 1974. An introduction to the ecology of the Illinois Orchidaceae. Illinois State Museum Scientific Papers XIV. Illinois State Museum, Springfield. xiii +89 pp.

Sheviak, C.J. 1979. Opuntia fragilis (Cactaceae) verified in Illinois flora. Brittonia 31:478-479.

Sheviak, C.J. 1981. Endangered and threatened plants. Pages 70-179 in M.L. Bowles, V.E. Diersing, J.E. Ebinger, and H.C. Schultz, eds. Endangered and threatened vertebrate animals and vascular plants in Illinois. Illinois Department of Conservation, Springfield. 189 pp. + vi appendices.

Smith, G.S. 2002. Schoenoplectus in Flora of North America North of Mexico 23:44-60.

Strother, J.L. 2006. Hymenmopappus in Flora of North America north of Mexico 21:309-316.
Swink, F. 1969. Plants of the Chicago region. The Morton Arboretum, Lisle, Illinois. xxii + $445 \mathrm{pp}$.

Swink, F., and G. Wilhelm. 1979. Plants of the Chicago region. Revised and expanded edition with keys. The Morton Arboretum, Lisle, Illinois. lxxiii + 922 pp.

Swink, F., and G. Wilhelm. 1994. Plants of the Chicago region. $4^{\text {th }}$ Edition. Indiana Academy of Science, Indianapolis. xiv + 921 pp.

Taft, J.B., B. Molano-Flores, and J.O. Dawson. 2009. Pages 229-249 in C.A. Taylor, J.B. Taft, and C.E.Warwick, eds. Canaries in the catbird seat. Illinois Natural History Survey Special Publication 30.

Tehon, L.R. 1942. Fieldbook of native Illinois shrubs. Illinois Natural History Survey, Manual 3, Urbana. 307 pp.

Todd, B.L., J.M. Coons, and H.R. Owen. 2002. Scarification technique affects germination of Stylisma pickeringii (Paterson bindweed), an Illinois endangered plant. American Midland Naturalist 148:190-192.

Tucker, G.C., B.G. Marcks, and J.R. Carter. 2002. Cyperus in Flora of North America North of Mexico. 23:141-191.

Turner, B.L. 1956. A cytotaxonomic study of the genus Hymenopappus (Compositae). Rhodora 58:163-186, 208-242, 250-269, 295-308.

van der Valk, A.G. 1981. Succession in wetlands: A Gleasonian approach. Ecology 62:688-696.

Vasey, G. 1861a. Additions to the flora of Illinois. Transactions of the Illinois Natural History Society 1:139-143.

Vasey, G. 1861b. Additions to the flora of Illinois. Transactions of the Illinois State Agricultural Society 4:667-671. 
Vasey, G. 1870. Maritime plants of the Great Lakes and the interior. The American Entomologist and Botanist 2:342-344.

Vestal, A.G. 1913. An associational study of Illinois sand prairie. Illinois State Laboratory of Natural History Bulletin 10:1-96.

Visocky, A.P. 1995. Determination of 100-year ground-water flood danger zone for the Havana and Bath area, Mason County, Illinois. Contract Report 584. Illinois State Water Survey, Champaign. $15 \mathrm{pp}$.

Voss, J. 1935. Actinea herbacea. Torreya 62:61-62.

Wagner, Jr. W.H., and F.S.Wagner. 1993. Ophioglossaceae in Flora of North America North of Mexico 2:85-106.

Warne, H.A. 1870. List of plants growing in the vicinity of Chicago during March, April, and May. American Entomologist and Botanist 2:313-314; 345-348.

Wayne, F.E. 1944. Drosera in eastern North America. Bulletin of the Torrey Botanical Club 71:166-174.

Wheeler, L.C. 1941. Euphorbia subgenus Chamaesyce in Canada and the United States exclusive of southern Florida. Rhodora 43:97154; 168-205, 223-286.

White, J. 1978. Illinois natural areas inventory technical report. Volume I. Survey methods and results. Illinois Department of Conservation, Department of Landscape Architecture at the University of Illinois at Urbana-Champaign, and Natural Land Institute, Springfield. 426 pp.

White, J., and M.H. Madany. 1978. Classification of natural communities in Illinois. Pages 310-405 in J. White, ed. Illinois natural areas inventory. Technical report. Illinois Natural Areas Inventory, Urbana.
Whittemore, A.T., and A.E. Schuyler. 2002. Scirpus in Flora of North American North of Mexico 23:8-21.

Wiggers, R. 1997. Geology underfoot in Illinois. Mountain Press Publishing, Missoula, Montana. 300 pp.

Willman, H.B. 1973. Geology along the Illinois waterway - a basis for environmental planning. Illinois State Geological Survey Circular 478. Urbana. 48 pp.

Willman, H.B., and J.C. Frye. 1970. Pleistocene stratigraphy of Illinois. Illinois State Geological Survey Bulletin 94:1-204.

Winterringer, G.S. 1967. Wild orchids of Illinois. Popular Science Sceries VI. Illinois State Museum, Springfield. 130 pp.

Wipff, J.K. 2003. Bouteloua in Flora of North America North of Mexico 25:250-269.

Wunderlin, R.P. 1971. Contributions to an Illinois flora no. 4. Compositae II (Tribe $\mathrm{He}$ liantheae, Part I-Dyssodia, Helenium, Gaillardia, Hymenoxys, Hymenopappas, and Polymnia). Transactions of the Illinois State Academy of Science 64:317-327.

Yatskievych, G. 1999. Steyermark's Flora of Missouri Volume 1, revised edition. The Missouri Department of Conservation, Jefferson City. Xii + 991 pp. 



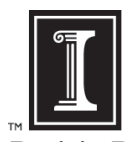

Prairie Research Institute Illinois Natural History Survey Forbes Natural History Building 1816 South Oak Street

Champaign, Illinois 61820

217-333-6880 